\title{
Deciphering mechanisms of immune escape to inform immunotherapeutic strategies in multiple myeloma
}

\author{
Muthulekha Swamydas ${ }^{1}$, Elena V. Murphy ${ }^{2}$, James J. Ignatz-Hoover ${ }^{1,3}$, Ehsan Malek ${ }^{1,3}$ and James J. Driscoll ${ }^{1,3^{*}}$ (D)
}

\begin{abstract}
Multiple myeloma is an incurable cancer characterized by the uncontrolled growth of malignant plasma cells nurtured within a permissive bone marrow microenvironment. While patients mount numerous adaptive immune responses directed against their disease, emerging data demonstrate that tumor intrinsic and extrinsic mechanisms allow myeloma cells to subvert host immunosurveillance and resist current therapeutic strategies. Myeloma downregulates antigens recognized by cellular immunity and modulates the bone marrow microenvironment to promote uncontrolled tumor proliferation, apoptotic resistance, and further hamper anti-tumor immunity. Additional resistance often develops after an initial clinical response to small molecules, immune-targeting antibodies, immune checkpoint blockade or cellular immunotherapy. Profound quantitative and qualitative dysfunction of numerous immune effector cell types that confer anti-myeloma immunity further supports myelomagenesis, disease progression and the emergence of drug resistance. Identification of tumor intrinsic and extrinsic resistance mechanisms may direct the design of rationally-designed drug combinations that prevent or overcome drug resistance to improve patient survival. Here, we summarize various mechanisms of immune escape as a means to inform novel strategies that may restore and improve host anti-myeloma immunity.
\end{abstract}

Keywords: Multiple myeloma, Immunotherapy, Immune escape, Drug resistance, Proteasome, Cytotoxic T cell, NK cell, CART cells

\section{Background}

Multiple myeloma (MM) is a malignant neoplasm characterized by the progressive growth and proliferation of clonally-transformed plasma cells (PCs) that reside within bone marrow (BM) [1-3]. MM is the second most common hematologic malignancy with $>160,000$ new cases occurring every year globally and $\sim 35,000$ per year in the U.S $[4,5]$. MM follows a multistep process that includes tumor immune escape and the accumulation of genomic alterations within the malignant clone(s) that drive progression from precursor stages, i.e., monoclonal

\footnotetext{
*Correspondence: james.driscoll@UHhospitals.org

1 Seidman Cancer Center, University Hospitals, Cleveland, OH, USA

Full list of author information is available at the end of the article
}

gammopathy of unknown significance (MGUS) and smoldering MM (SMM) [4, 6-8]. Overt MM is characterized by the accumulation of clonal PCs within BM that promotes end organ dysfunction clinically recognized as anemia, lytic bone disease, hypercalcemia, and renal injury $[1,7]$.

Modern myeloma therapy has greatly improved patient outcomes with 5-year overall survival (OS) nearly doubling from 32\% in 1996 to $54 \%$ in 2020 [9]. In addition to immunomodulatory drugs (IMiDs) and proteasome inhibitors (PIs), the anti-CD38 antibody (Ab) daratumumab was approved for relapsed and/or refractory MM (RRMM) and has moved into the frontline setting for newly diagnosed MM (NDMM) [10-14]. Despite these improvements, $M M$ remains incurable, and further original author(s) and the source, provide a link to the Creative Commons licence, and indicate if changes were made. The images or other third party material in this article are included in the article's Creative Commons licence, unless indicated otherwise in a credit line to the material. If material is not included in the article's Creative Commons licence and your intended use is not permitted by statutory regulation or exceeds the permitted use, you will need to obtain permission directly from the copyright holder. To view a copy of this licence, visit http://creativecommons.org/licenses/by/4.0/. The Creative Commons Public Domain Dedication waiver (http://creativeco mmons.org/publicdomain/zero/1.0/) applies to the data made available in this article, unless otherwise stated in a credit line to the data. 
research into myelomagenesis and drug resistance is needed [10-12]. Of particular interest is the tumor microenvironment (TME) and mechanisms of immunological escape that foster disease progression $[13,14]$. Here, we discuss tumor intrinsic and extrinsic mechanisms of immune escape that promote resistance to antimyeloma immunity.

\section{Tumor-intrinsic mechanisms of immune escape in myeloma}

Recent pre-clinical and clinical studies support the strategy that triggering host immunity is critical for most antimyeloma therapies to be effective [11-14]. PIs, IMiDs, monoclonal Abs (mAbs), autologous stem cell transplantation (ASCT), T cell-based immunotherapy, e.g., chimeric antigen receptor (CAR) $\mathrm{T}$ cells and bispecific $\mathrm{T}$ cell engagers (BiTEs), have shown clinical benefit in RRMM $[15,16]$. MM is characterized by disrupted immune surveillance, impaired $\mathrm{Ab}$ production, deregulated $\mathrm{T}$ and NK cell compartments, disrupted antigen presentation, upregulation of inhibitory surface ligands, and recruitment of immunosuppressive cells [17].

\section{Immunoediting}

Immunosurveillance specifies the host immune reaction against tumor cells while immune escape refers to tumor cell evasion of host immunity $[18,19]$. Immune escape in $\mathrm{MM}$ is driven by immunoediting in which the immune system protects the host [20-22]. However, the immune system also places evolutionary pressure on malignant cells causing them to undergo immunogenic sculpting that enables immune escape and disease progression [23, 24].

Immunoediting proceeds through the three phases; elimination, equilibrium, and escape. During elimination, transformed cells that have escaped normal cell-intrinsic apoptotic/senescence checkpoints are recognized and killed by cells of the innate and adaptive immune systems. In the equilibrium stage, tumor subclones that survived elimination through the acquisition of additional genetic alterations, begin to expand. However, overall net tumor growth is prevented primarily by adaptive immunity $[23,25]$. Over time, the evolutionary pressure placed on the developing tumor promotes the selection and expansion of tumor subclones. In the last stage, tumor outgrowth is no longer restricted by host immunity and tumor subclones emerge evidenced by clinically apparent disease. While the immune system is capable of recognizing and killing MM cells to constrain tumor growth, the same mechanism also promotes the emergence of malignant subclones [26].

\section{Loss of antigenicity}

Immunosurveillance is dependent on the recognition of tumor antigens and loss of tumor antigenicity is observed in MM [27]. Lack or loss of tumor antigenicity represents a key mechanism of immune escape and resistance to $\mathrm{T}$ cell-based immunotherapies. During myelomagenesis, aberrant expression of cancer-related genes and protein products initially promotes a cellular immune response. Reduced or defective expression of tumor antigens or major histocompatibility complexes (MHC) along with defects in antigen processing and presentation help tumor cells escape cytotoxic T lymphocytes (CTLs) [28, 29]. Elucidation of immune deficits that promote cancer progression has been difficult and lacks a unifying mechanism [28, 30, 31].

Loss of antigenicity through MHC class I downregulation or changes in tumor-associated antigen epitopes affect CTL responses in cell lines. Studies using murine models and clinical trials demonstrate that this phenomenon impacts anti-cancer treatment strategies [27, 29, 31]. High, uniform expression of CD38 by myeloma cells, combined with its role in cell signaling, demonstrates that CD38 is a viable therapeutic target in myeloma patients. Ise et al. reported loss of CD38 on MM cells in RRMM patients [32]. Loss-of-function of $\gamma$-aminobutyric acid receptor-associated protein (GABARAP) has also been identified as a tumor-intrinsic mechanism of resistance to bortezomib-induced cell death [33]. Lozano et al. reported that levels of CD85j (leukocyte immunoglobulin-like receptor B1, LILRB1), an inhibitory immune checkpoint for B cell function, were significantly lower in MM patients [34]. Reduced CD85j levels correlate with phenotypically aberrant PCs in MM patients. Decreased CD85j expression was detected in MGUS patients to suggest that $C D 85 j$ loss is an early event in immune escape. Gene expression profiling of CD85j-overexpressing MM cells revealed a set of downregulated genes with crucial functions in $M M$ pathogenesis and that $C D 85 j$ overexpression increased susceptibility to $\mathrm{T}$ cell- and NK cell-mediated killing. Downregulation of inhibitory immune checkpoints on MM cells provides a mechanism of immune escape associated with myeloma pathogenesis [34].

\section{Alterations in antigen processing and presentation}

Immune evasion is a cancer hallmark [35, 36], and MM cells employ multiple strategies to downregulate MHC class I expression to impair CTL recognition of tumor cells (Fig. 1). Impaired antigen presentation is a highly studied mechanism of immune evasion exploited by cancer cells. Defects in the function of any of these components affects peptide production, antigen presentation 


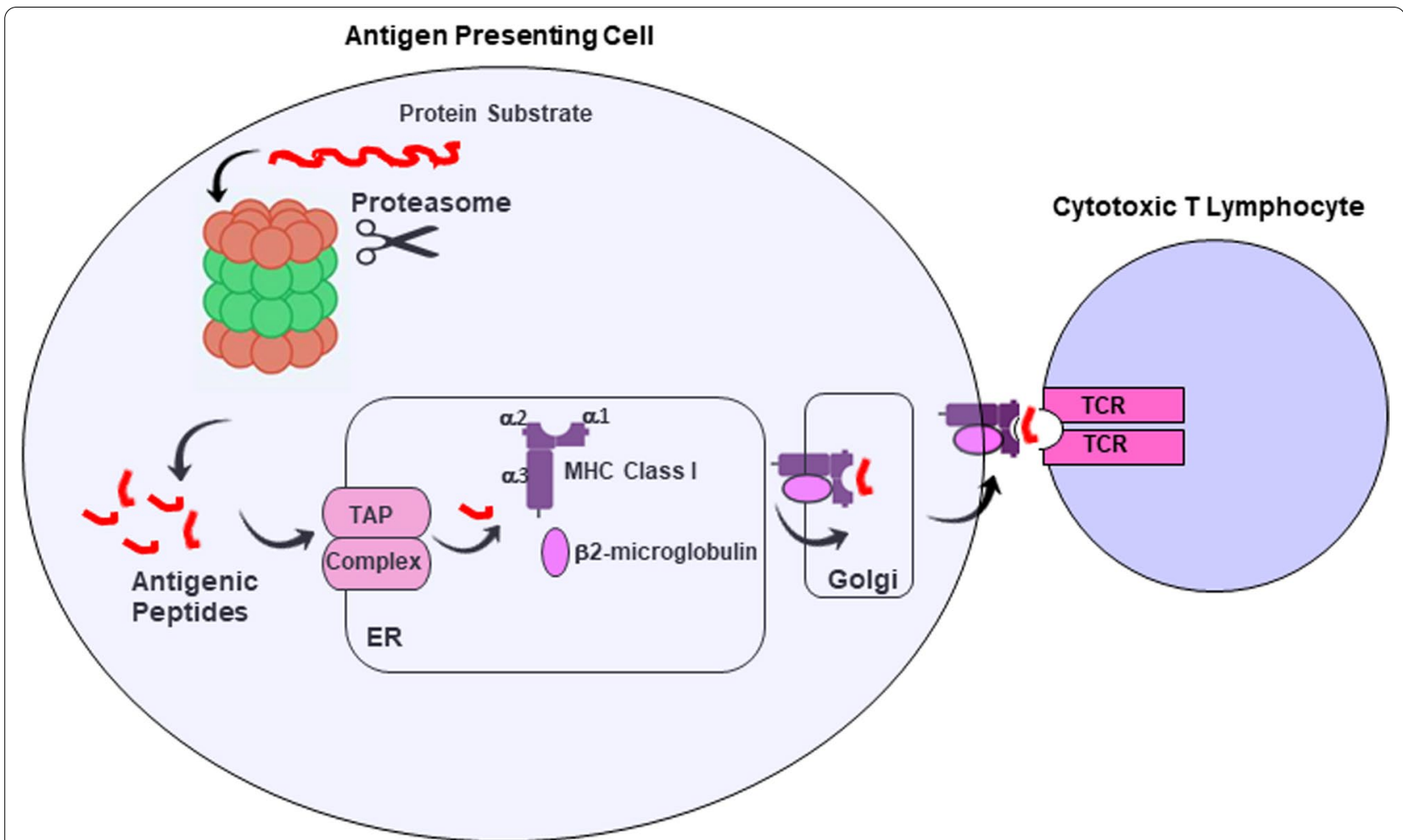

Fig. 1 Proteasomal processing and presentation of MHC class I antigens. Proteasomes are essential for immune surveillance and cleave intracellular antigens to provide peptides that are presented on the tumor cell surface to CTLs. Proteasome are key effectors in the cascade of proteolytic processing events required for the generation of antigenic peptides. Resistance to CTLs is mediated by the loss of MHC class I expression or IFN- $\gamma$ signaling within tumor cells

and their recognition by CD8 $+\mathrm{T}$ cell receptors (TCRs). MM patients exhibit disruption in the presentation of class I antigens and altered expression of key players in antigen processing alters the repertoire of peptide antigens [35]. Racanelli et al. showed that malignant PCs from MM patient BM express reduced levels of antigen processing machinery (APM), i.e., constitutive and immunoproteasome subunits and TAP1/TAP2 transporters while protein chaperones, HLA class I and beta-2 microglobulin are increased in MM. Changes in the APM are associated with modified peptide repertoires to reduce the presentation of tumor-associated antigens (TAA) as well as reduced CD8 $+\mathrm{T}$ cell cytotoxic capacity [36].

Processing of MHC HLA class I antigens is accomplished through protein degradation by the constitutive proteasome as well as the immunoproteasome [37-39]. TAAs originate from the degradation of cellular proteins into short peptides that are cleaved by a specialized form of the proteasome in the cytosol known as the immunoproteasome [43]. Peptides generated by proteasomes are transported to the ER and associate with HLA class I heavy chains. IFN- $\gamma$ triggers transcriptional increases in expression of at least five immunoproteasome subunits which cooperate to form immunoproteasomes (Fig. 2). New catalytic subunits ( $\beta 1 \mathrm{i}, \beta 2 \mathrm{i}$, and $\beta 5 \mathrm{i})$ are incorporated into $20 \mathrm{~S}$ proteasomes to alter the catalytic specificities of proteasomes.

\section{Genomic alterations that reduce immunity}

MM is characterized by genetic complexity and common events, e.g., hyperdiploidy, translocation of immunoglobulin heavy chain, and 13q deletion, confer an early clonal advantage [40, 41]. Patterns of genomic evolution have been characterized and subclones differentially proliferate based upon their fitness [42]. Genomic changes in MM cells are already present in PCs from MGUS patients prior to overt malignancy and immune recognition of MGUS lesions correlates with reduced risk of progression [43].

Genomic alterations within MM tumors have been shown to correlate with reduced sensitivity to a number of recently developed cell-based therapies. Homozygous deletion in chromosome 6 resulted in loss of $B C M A$ (TNFRSF17), indicating that this mutation may play a role in CAR $\mathrm{T}$ resistance [44]. Using whole genome 


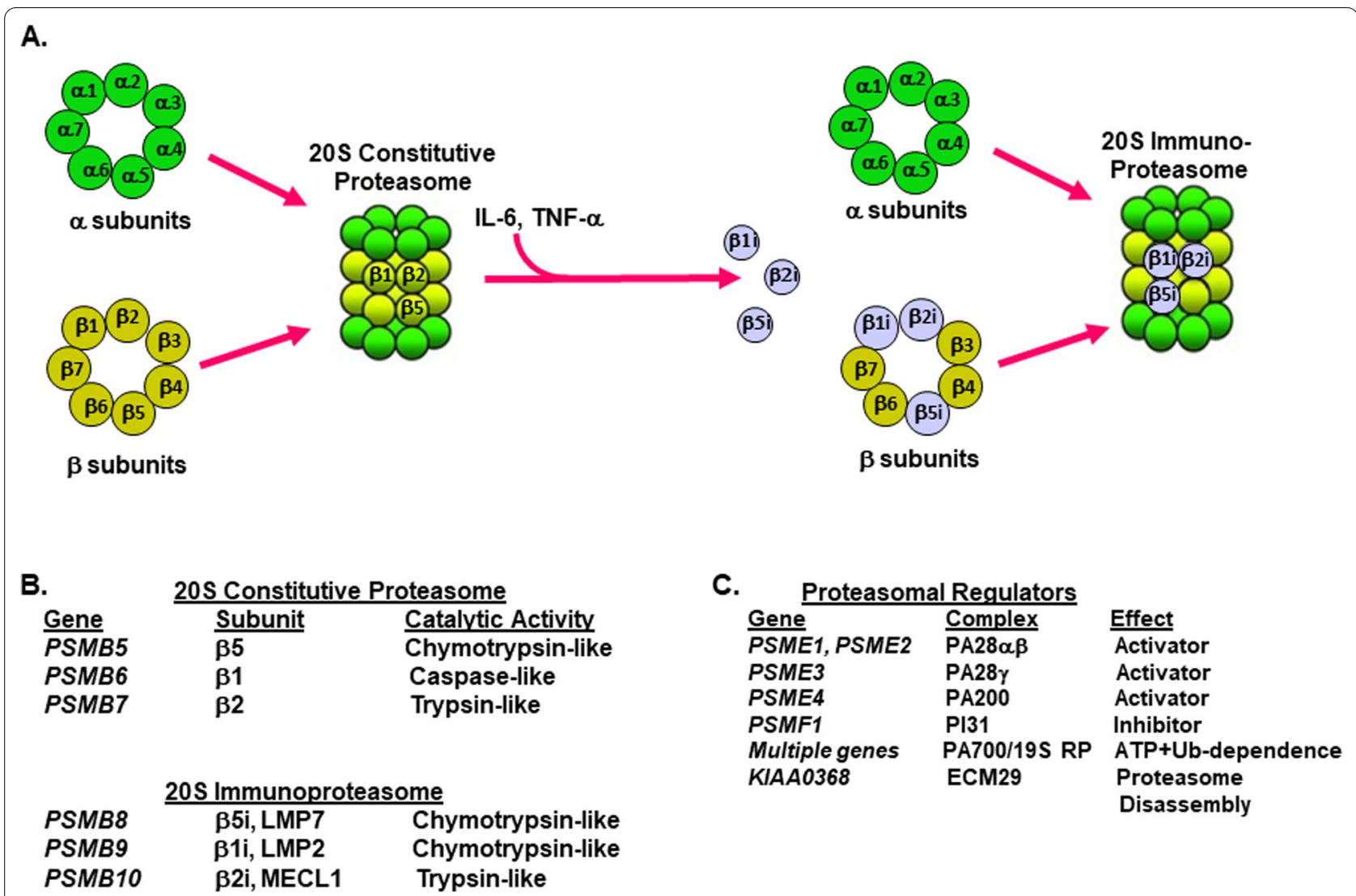

Fig. 2 Conversion of constitutive proteasomes to immunoproteasomes. a Schematic representation for formation of $20 \mathrm{~S}$ immunoproteasomes. To process antigens more efficiently, proteasomes replace some of its subunits to form immunoproteasomes. IFN- $\gamma$ and TNF-a trigger transcriptional increases in IFN- $\gamma$ that increase the expression of at least five immunoproteasome catalytic and activator subunits which cooperate to form $20 \mathrm{~S}$ immunoproteasomes. New catalytic subunits ( $\beta 1 \mathrm{i}, \beta 2 \mathrm{i}, \beta 5 \mathrm{i})$ and activator subunits (PA28a/ $\beta$ ) are incorporated into $20 \mathrm{~S}$ constitutive proteasomes. b Genes that encode constitutive proteasome and immunoproteasome catalytic subunits, the catalytic activities and substrate specificities are shown. c Proteasome regulators that activate or inhibit proteasome-related activities are shown

sequencing (WGS), heterozygous loss of BCMA in patients not exposed to BCMA CAR T cells indicated that TNFRSF17 deletion at baseline was a risk factor for BCMA-resistance after immunotherapy [44]. Samur et al. found biallelic mutation with deletion of one copy and loss-of-function of another copy of $B C M A$ as a chemoresistance mechanism in a patient with initial response to BCMA CAR $\mathrm{T}$ who later relapsed and developed resistance to treatment [31]. BCMA loss has also been reported in patients treated with BCMA-targeting bispecific antibodies. Truger et al. identified alterations in genes that encode immune targets that potentially act as biomarkers for treatment resistance seen clinically [45].

CAR $\mathrm{T}$ cells targeting the BCMA have resulted in deep responses in patients with relapsed MM however most remissions are not sustained. Maity et al. reported that BCL2L1 blockade of activation-induced cell death not only enhanced the viability and proliferation of BCMAtargeting CAR $\mathrm{T}$ cells but also reduced their functional exhaustion. The findings provide a novel approach to optimize CAR T cells and prevent $\mathrm{T}$ cell exhaustion [46].

Progression of MM during treatment is driven by a complex interplay between tumors and the surrounding immune microenvironment. Coffey et al. compared the cellular and humoral immunity of MM patients treated with lenalidomide maintenance to those who lost or were unable to attain minimal residual disease (MRD) negativity [47]. Patients that did not maintain MRD negativity had hallmarks of immune dysregulation at baseline and during lenalidomide maintenance, while those who achieved and sustained MRD negativity showed gradual normalization of the immune microenvironment. Exposure to high-dose melphalan (HDM) ASCT translated into cellular and humoral immunosuppression, which correlated with dynamics of MM recurrence. Independent of the impact of HDM-ASCT on host immunity, composition of the immune microenvironment varied according to the depth of response. 


\section{Immune checkpoint inhibitors}

Myeloma cells escape immunosurveillance through aberrant expression of cell surface antigens, quite different from those presented by healthy PCs [48]. MM patient tumor cells display increased expression of the immune-checkpoint receptor programmed cell death receptor ligand (PD-L1) relative to PCs from MGUS or healthy patients (Table 1). Increased PD-L1 expression is associated with reduced CTL-mediated tumor lysis, while elevated PD-L1 levels enhance regulatory T cells (Tregs) and further promote immune escape [49]. MM cells express greater levels of the inducible $\mathrm{T}$ cell co-stimulator ligand (ICOSL) and CD86, both of which increase $\mathrm{T}$ cell production of inhibitory interleukin (IL)10 [50]. Although MM cells express CD138, there is an enriched fraction of clonogenic CD138- cells that express high levels of the embryonic marker SOX2 [51]. T cells that recognize SOX2 are lacking in MM, but are detected in MGUS patients. Increased CD28 expression has a prosurvival effect through interaction with CD80/CD86 costimulatory molecules and increased IL- 6 production.

\section{Secretion of immunomodulatory molecules}

MM cells express the MHC class I chain-related polypeptides A (MICA) and MICB (MICB) that function as ligands for the activating NK group 2D (NKG2D) receptor present on NK and T cells [52]. Soluble MICA is shed from MM cells and downregulates NKG2D on NK cells. Since soluble NKG2D ligands are associated with poor clinical prognosis, harnessing the NKG2D pathway has emerged as a viable strategy.

\section{Exosomes}

Exosomes are a subset of extracellular vesicles (EVs) released by cells and have been shown to regulate the immune system. EVs are heterogeneous, present in vast numbers in the TME and exhibit immunosuppressive activity [53]. Tumor-associated exosomes facilitate tumor growth by affecting immune activation, antigen expression, and immune surveillance $[54,55]$. Exosomes within the TME can directly suppress $\mathrm{T}$ cell activation and drive differentiation of monocytes towards myeloid-derived suppressor cells (MDSCs) that then stimulate Tregs and suppress T cell activation [56]. Tumor-derived exosomes also promote M2-like macrophage polarization to enhance tumor progression [57]. Umezu et al. demonstrated that miRNA-135b from MM-derived exosomes accelerated hypoxia-inducible factor (HIF)-1 transcriptional activity [58]. Exosomes upregulate nitric oxide synthase in MDSCs to enhance immunosuppression [59].

\section{TGF- $\beta$ signaling}

Transforming growth factor- $\beta$ (TGF- $\beta$ ) plays an essential role in establishing immunological tolerance and

Table 1 Quantitative and qualitative changes in individual immune cell types and immune cell markers detected within the BM microenvironment of MGUS, SMM, NDMM and RRMM patients compared to BM samples obtained from healthy volunteers [113, 137, $143,184]$

\begin{tabular}{|c|c|c|c|c|}
\hline Immune cells and markers & MGUS & SMM & NDMM & RRMM \\
\hline $\mathrm{CD} 4^{+\mathrm{ve}} \mathrm{T}$ cells & No change & No change & Reduced & Reduced \\
\hline $\mathrm{CD}^{+\mathrm{ve}} \mathrm{T}$ cells & No change & No change & No change & No change \\
\hline $\mathrm{CD} 4^{+\mathrm{ve}} \mathrm{CD} 25^{\text {+ve }}$ Tregs & No change & No change & Increased & Increased \\
\hline PD1 expression on Tregs & No change & No change & Increased & Increased \\
\hline LAG3 expression on Tregs & No change & No change & No change & Increased \\
\hline Granulocytic MDSC & No change & No change & Increased & Further increased \\
\hline PD-L1 expression on Granulocytic MDSC & No change & No change & Increased & Increased \\
\hline Monocytic MDSC & No change & No change & No change & No change \\
\hline PD-L1 expression on CD138+ve MM cells & No change & No change & Increased & Increased \\
\hline NK cells & Slight Increase & ND & Increased & ND \\
\hline NKT cells & $\begin{array}{l}\text { Maintain their capacity for activation and } \\
\text { antibody-dependent cellular toxicity }\end{array}$ & ND & $\begin{array}{l}\text { Marked functional } \\
\text { deficits }\end{array}$ & ND \\
\hline Non classic CD $16^{\text {tve }}$ monocytes & Increased & ND & Increased & ND \\
\hline Classic CD14 ${ }^{+v e}$ monocytes & Normal/ Decreased & Decreased & Decreased & ND \\
\hline Plasmacytoid DC & Decreased & ND & Decreased & ND \\
\hline Monocytic DC & No change & ND & No change & ND \\
\hline M2macrophages & ND & ND & Increased & Further increased \\
\hline STAT3 activation in TAMS & Increased & ND & Increased & ND \\
\hline
\end{tabular}


recent studies have revealed the pro-inflammatory roles of TGF- $\beta$ in inflammatory responses [60]. TGF- $\beta$ also supports MM progression, the emergence of drug resistance and the progression of osteolytic bone disease [61]. TGF- $\beta$ induces Foxp3-positive regulatory $\mathrm{T}$ cells (iTregs) as well as pathogenic IL-17-producing Th17 cells [62-64]. Vactosertib (TEW-7197) is a TGF- $\beta$ type I receptor (TGF- $\beta$ RI) kinase inhibitor used in combination with pomalidomide (Pom) (NCT03143985) [64, 65]. Vactosertib suppresses myeloma viability, impairs bone resorption and modulates the TME in immunocompetent mice. Efficacy assessment (PFS-6, 80\%) was greater with vactosertib and Pom (PFS-6, 20\%) than with Pom alone (PFS-6, 20\%) or Pom with corticosteroids (PFS-6: 40\%) [66].

TAAs released upon cancer cell death are processed and presented by dendritic cells (DCs) in order to prime and activate $\mathrm{T}$ effector cells, especially CTLs [67]. Activated tumor-specific CTLs then migrate and infiltrate the tumor bed to recognize TAAs bound on MHC class I molecules, leading to $\mathrm{T}$ cell-mediated cytotoxicity [68, 69]. While the presence of tumor-infiltrating lymphocytes (TILs) is associated with improved prognosis, TILs may become inactive in response to tumor-derived signals within the TME. Mutation of $\beta 2 \mathrm{~m}$, a component of the MHC-I molecule, may lead to an absence of MHC-I expression [70]. Downregulation of proteasome components and MHC complexes involved in TAA presentation may limit anti-tumor immunity.

\section{Tumor extrinsic mechanisms of immune escape in $\mathbf{M M}$}

B cell dysfunction in MM is characterized by immunoparesis, hypogammaglobulinemia and increased susceptibility to infection [71]. Effectors of anti-tumor immunity helped by antigen-presenting DCs mediate protective immune responses against tumors in healthy BM. However, in MM, tumor cells create an immunosuppressive TME which increases the number of tumor suppressive cells, e.g., Tregs, MDSCs, and reduce CTLs resulting in decreased humoral and cytotoxic immunity [71].

\section{T cells}

Efficiently activated immune competent $\mathrm{T}$ cells in TMEs are required for the successful destruction of the tumor cells by the immune system. Deficiencies in $\mathrm{T}$ cell activity and tissue distribution have been reported

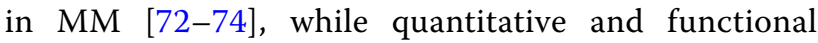
impairment of $\mathrm{T}$ cell functioning has been described in MM and MGUS patients. Severe defects in T cell diversity has also been shown in MM patients [74, 75]. T cell subsets in MM patients are frequently abnormal and a significant reduction in the $\mathrm{CD} 4 / \mathrm{CD} 8$ ratio has been reported in MM patients relative to healthy controls $[76,77]$. Reduction in CD4+ T cells correlates with reduced progression free survival (PFS) and overall survival (OS) [78]. While the percentage of CD8+ effector cells is increased within the tumor site, these cells are functionally exhausted due to prolonged antigen exposure and are characterized by increased expression of inhibitory receptors [79]. Studies have also shown that $\mathrm{T}$ cells may exhibit a senescent phenotype in addition to exhaustion [80]. Soluble factors within the TME also contribute to defective $\mathrm{T}$ cell activity. T cells from MM patient peripheral blood (PB) demonstrate reduced IFN- $\gamma$ production and tumor recognition, and defective antitumor activity in vivo. Reduced IFN- $\gamma$ levels and increased IL-4 levels in patient serum indicate a shift towards Th2 polarization. IL- 6 produced in the myeloma TME reduces the Th1 response [71, 81], while an increased Th1/Th2 ratio and high IFN- $\gamma$-producing $\mathrm{T}$ cells have been reported in the $\mathrm{PB}$ of MM patients $[82,83]$.

The $\mathrm{CD} 4+\mathrm{CD} 25+$ Treg population is increased in $\mathrm{MM}$ patient $\mathrm{PB}$ and overexpression of the transcription factor Foxp3 in CD4+CD25 + cells correlates with immunosuppressive activity [84, 85]. Tregs from MM patients are efficient in suppressing antigen-presenting cells (APCs) as well as T cell proliferation [85, 86], while MM patients with increased Treg frequencies correlate with shorter time to progression and reduced survival [87]. Tregs from MM patients express increased amounts of TGF- $\beta$ and IL- 10 compared to healthy controls indicating a more suppressive phenotype [85]. Tregs also secrete granzyme B and have the capacity to kill CTLs, B cells and NK cells. Tregs suppress DC function by upregulating indolamine dioxygenease (IDO) and through interaction of CTLA-4 and Lymphocyte Activation Genes (LAG)-3 ligands present on DCs [88]. Even though IL-6 in $M M$ increases Treg frequencies, the mechanism by which MM cells induce Tregs is poorly understood [86, 89]. Tregs decrease the clinical response upon treatment with talquetamab, a bispecific mAb (BCMA) directed against the G protein-coupled receptor GPRCD5D. Tregs reduced $M M$ cell lysis in response to talquetamab by decreasing $\mathrm{T}$ cell activity and by decreased production of the pro-inflammatory cytokines IFN- $\gamma$, TNF- $\alpha$ and IL-2 [90].

Inflammatory Th17 cells secrete IL-17 and IL-22 and differentiate in the presence of IL-6, IL-1, IL-21 and IL-23 to express the transcription factor RAR-related orphan receptor $\gamma \mathrm{T}$ (ROR $\gamma \mathrm{t}$ ) [91]. IL-17 promotes myeloma growth and colony formation through the IL-17 receptor as well as adhesion to BM stromal cell (BMSC). Th17 cells have a reciprocal relationship with Tregs during development that is dependent upon IL- 6 and TGF- $\beta$ levels [92]. 
T cells that express CD86 and HLA-G are increased in the PB of MM patients relative to healthy controls [93]. T cells acquire tumor-derived neoantigens during trogocytosis, a unidirectional TCR-and HLA-independent process that results in immunophenotypically novel Tregs [94-96]. HLA-G + and CD86 + T cells have been shown to be immunosuppressive [97] and trogocytosis has been shown to adversely affect checkpoint inhibitor treatment [98].

\section{NK cells}

NK cells kill MM cells by releasing lytic granules containing granzymes and perforin $[99,100]$. NK cells recognize myeloma cells that downregulate the MHC I receptor and express high levels of MICA [52, 101, 102]. NK cells also reduce MM proliferation in vitro through IFN- $\gamma$ and IFN- $\gamma$-deficient mice demonstrate reduced survival when injected with MM cells $[2,103]$.

PB from MGUS and MM patients demonstrate increased numbers of NK cells, while in advanced MM patients, the number of NK cells in PB is reduced compared to MGUS patients $[104,105]$. NK cells in the TME exhibit an exhausted phenotype characterized by downregulation of NK cell activation receptors and upregulation of the programmed cell death receptor-1 (PD-1) [102, 106, 107]. NK2GD, natural cytotoxicity receptors (NCRs), and DNA accessory molecule-1 (DNAM-1, CD226) are also reduced in BM, while activation receptor $2 \mathrm{~B} 4$ is reduced in both $\mathrm{PB}$ and $\mathrm{BM}[52,108,109]$. Reduced expression of activation receptors reduce NK cell cytotoxic capabilities and reduce PC killing in spite of reduced HLA class I expression [110, 111]. Ligands expressed by PCs that help recognition by NK cells are also reduced in MM. Expression of the stress-induced ligand MICA that binds the NK cell receptor is reduced during the MGUS transition to MM. In addition, expression of ligands recognized by the NKP30 receptor are also reduced preventing the recognition and killing of myeloma cells [112]. Even at early stages of myeloma, HLA class I expression is reduced and higher levels of HLA class I expression are noted in the pleural effusions of patients with advanced MM $[52,101,113]$. HLA-E is a non-classical MHC class I molecule which plays a critical role in the immune response by both inhibiting and activating the function of NK cells through interaction with NKG2A receptors [114]. HLA-E expression correlates with worse PFS in newly diagnosed, treatment-naïve MM patients.

\section{$B$ regulatory cells}

Immunosuppressive B regulatory cells (Bregs) maintain immune tolerance through IL-35, TGF- $\beta$ and IL-10 secretion as well as expression of inhibitory molecules, e.g., PD-L1 [115-118]. Bregs are highly heterogenous and range from immature CD24hi CD38hi cells to highly differentiated CD38 + CD27hi PCs [119]. Through IL-10 production, Bregs suppress Th1, Th2, and Th17 production, differentiation and secretion of pro-inflammatory cytokines. Bregs also induce differentiation of Foxp3+ Tregs $[82,120,121]$ and inhibit antigen presentation by mononuclear cells, macrophages, and DCs [122]. Bregs are capable of suppressing anti-myeloma cell antibody-dependent cellular cytotoxicity (ADCC) by NK cells [123]. The percentage of immunosuppressive IL-10-producing Bregs is significantly increased in MM patients compared to healthy controls. Daratumumab has also been shown to reduce the number in Bregs in BM [124].

\section{Dendritic cells}

Myeloma cells affect the generation and differentiation of DCs, and therefore, antigen presentation through direct interaction with DCs. Cytokine-mediated activation of the p38/MAPK pathway affects DC generation and differentiation in BM [125-127]. Myeloid-derived DCs in myeloma patient BM interact directly with tumor cells, downregulate proteasome subunits, and confer resistance to CD8 + T cells [128]. DCs in the TME also increase Foxp3 expression in CD4+ T cells and increase proliferation of Foxp3-expressing immunosuppressive Treg cells [129].

\section{Tumor-associated macrophages (TAMs)}

Macrophages are abundant within the TME and tumorassociated macrophages (TAMs) play a major role in MM survival and proliferation [130, 131]. MM-associated macrophages are derived from the maturation of circulating monocytes that have been recruited to the tumor [132]. TAMs are a heterogeneous population classified into M1 (classical macrophages) with immunostimulatory properties and M2 (activated macrophages) with immunosuppressive properties [133]. MM-associated macrophages display more M2-like properties with limited cytotoxicity, reduced antigen presentation, increased angiogenesis and $\mathrm{T}$ cell suppression [134]. Extracellular vesicles $(E V)$ released by $M M$ cells polarize recruited monocytes to an M2 phenotype [135]. Macrophages activate signaling pathways that aid in disease progression and the development of drug resistance by direct interaction with myeloma cells, cytokines and growth factors $[134,136]$. Macrophages also directly interact with MM cells to reduce the activation and cleavage of caspasedependent apoptosis and promote chemo-resistance $[137,138]$. Myeloma-associated macrophages also are a major source of IL-6, IL-10 and IL-1 $\beta$ that help in tumor proliferation and survival $[139,140]$. Macrophages are 
a source of pro-angiogenic VEGF, FGF-2 and IL-8 that promote neovascularization [134]. Macrophages from the TME exhibit a vascular, endothelial phenotype when treated with VEGF and FGF [141].

\section{Myeloid-derived suppressor cells (MDSCs)}

MDSCs are a heterogeneous population of immature myeloid cells that accumulate in the TME as tumors progress [142-144]. MDSCs promote tumor development through immunosuppression of innate and adaptive immunity through secretion of cytokines and growth factors $[145,146]$. MDSC are defined as granulocytic (G-MDSC, CD11b+, CD33+, HLADR-/low, CD14-, Lox1+) or monocytic (Mo-MDSC, CD11b+, CD33+, HLADR-/low, CD14+) [147, 148]. G-MDSCs and MoMDSCs are increased in MM patient PB and BM compared to healthy controls $[144,149,150]$ and MDSC accumulation in PB correlates with disease activity, treatment response and relapse [143, 151].

MDSCs express immunosuppressive factors arginase, nitric oxide (NO) and reactive oxygen species (ROS) which enhance CD3 ligation that suppresses T cell proliferation and activation [152]. NO and superoxides produced by MDSCs increase nitration of TCRs in the TME to alter their binding to $\mathrm{MHC}$ molecules and impair antigen-specific $\mathrm{T}$ cell responses. MDSCs also downregulate $\mathrm{CD} 62 \mathrm{~L}$ in $\mathrm{T}$ cells and impair their migration to tumor sites [153]. MDSCs induce Th17 differentiation which promotes chronic inflammation and angiogenesis. IL-17 production and chronic inflammation promote recruitment of MDSC to the tumor site [154]. IL-10 produced by MDSCs induce Tregs and enhance immunosuppression at the tumor site [151]. MDSCs also promote immune escape through overexpression of PD ligands and suppress NK cell activity $[155,156]$. Crosstalk between MDSC and tumor-associated macrophages promotes cytokine release to promote M2 macrophage differentiation and tumor survival $[157,158]$.

\section{High density neutrophils}

Although neutrophils are the first line of host defense, recent studies have demonstrated an immunosuppressive role for high density neutrophils (HDNs) in MM [159]. Clinically, the ratio between the absolute neutrophil count (ANC) and lymphocytes has been shown to be predictive of OS and disease outcome in hematologic malignancies [160]. Neutrophils from MM patients display a different morphology, phenotype and gene expression patterns compared to those from healthy donors. HDNs express elevated levels of arginase that contribute to immunosuppression, reduced phagocytosis and less oxidative burst that may be corrected by arginase inhibitors [161]. Increased arginase expression also correlates with STAT-1 and STAT-3 signaling, to suggest an association with triggering of type 2 cytokine receptors resulting in chronically-activated neutrophils. Neutrophils in the TME show a progressive increase in autophagy and JAK/STAT signaling to support pro-inflammatory, survival signals $[161,162]$.

HDNs suppress $\mathrm{T}$ cell proliferation and activation and contribute to immunosuppression [163].

\section{Tumor microenvironment suppression of immune responses}

The TME is a highly complex, continuously evolving entity that supports bidirectional, mutually beneficial communication between malignant $\mathrm{PCs}$ and the $\mathrm{BM}$ milieu (Fig. 3). The TME serves as a protective niche to promote tumor growth, drug resistance and impairs immune surveillance [164]. Hallmark features of the TME include immune and stromal cells, blood vessels, and extracellular matrix. The TME is not just a silent bystander, but rather an active promoter of cancer progression [165]. In MM, complex crosstalk between hematopoietic stem cells, myeloid cells, $\mathrm{T}$ and $\mathrm{B}$ lymphocytes, NK cells, erythrocytes, osteoclasts as well as (non-hematopoietic) osteoblasts, stromal cells, e.g., fibroblasts, endothelial cells, and acellular components, e.g., extracellular matrix and cytokines, growth factors and chemokines produced by cellular components play an integral role in tumor progression and immune resistance $[12,166]$.

In MM patients, the TME exhibits increased levels of IL-6, IL-10, and TGF- $\beta$ that downregulate NK cell receptors and ligands. These changes contribute to functionally defective NK cells that exhibit a CD95- MHC class 1hi, MICA low phenotype [167]. IL-10 also inhibits production of the pro-inflammatory cytokines, e.g., TNF- $\alpha$ and IFN- $\gamma$ and reduced IFN- $\gamma$ levels further contribute to NK cell dysfunction. Soluble factors produced in the TME, e.g., prostaglandin E2 and indolamine hydrogenase, also inhibited NK cytotoxic activity. Hypoxia present in the BM TME further contributes to reduced NK cell responses in myeloma $[168,169]$.

The TME of MM can critically impair therapy outcome, including immunotherapies. Matrix proteins and BMSCs interact with MM cells to reduce immunosurveillance [170]. NF- $\kappa \mathrm{B}$-dependent adhesion of myeloma cells to BMSCs triggers IL-6 secretion to inhibit NK cytotoxicity. MM cells secrete growth factors, e.g., TGF- $\beta$ and VEGF, that inhibit T, NK and DCs, promote angiogenesis and upregulate IL-6 secretion. Vascular endothelial cells along with stromal cells suppress CTL and NK cellmediated tumor killing by deregulating components of the apoptotic machinery. BM mesenchymal stromal cells (BMMSCs) protect MM cells against the lytic activity of 


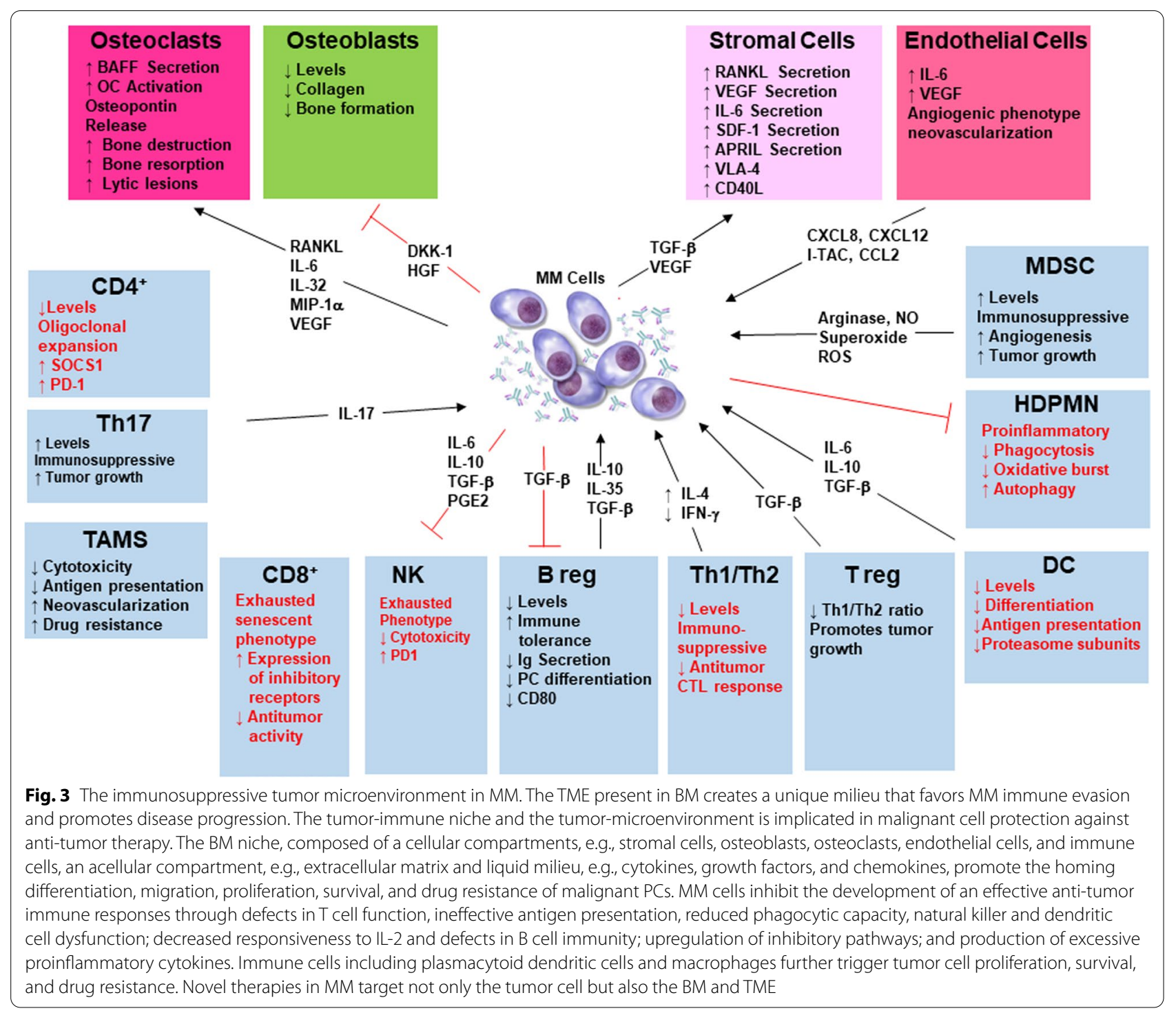

MM-reactive CTLs and daratumumab-redirected NK cells through upregulation of the anti-apoptotic proteins Survivin and Mcl-1. Holthoff et al. demonstrated the negative impact of the TME against immunotherapies and suggest that outcome of CAR T cell or conventional CTL therapies could benefit from inhibition of anti-apoptotic proteins upregulated in MM cells through BMMSC interactions. BMMSC-mediated protection of MM cells is not through reduction of granzyme B or IFN- $\gamma$ but through upregulation of anti-apoptotic machinery and can be completely overcome by the small molecule antiapoptotic inhibitor FL118 [171].

$\mathrm{BM}$ osteoclasts secrete a proliferation-inducing ligand (APRIL) to upregulate $T G F-\beta, I L-10$ and $P D-L 1$ levels and enhance immunosuppression [164, 172]. APRIL binds TACI, a member of the tumor necrosis factor (TNF) superfamily expressed on Tregs, BMSCs and PCs to promote Treg viability. APRIL also increases Treg induction by MM cells to enhance Treg-mediated inhibition of T cell activity [173]. BMSC-derived exosomes further promote MM proliferation, migration, and survival, induce drug resistance and influence signaling pathways [174].

Blinatumomab can induce a complete hematological remission in patients in $46.6 \%$ with relapsed/refractory B-precursor acute lymphoblastic leukemia $(\mathrm{r} / \mathrm{r}$ ALL) resulting in a survival benefit compared to chemotherapy. Only BM blast counts before therapy have shown a weak prediction of response. The frequency of Tregs, measured by CD4/CD25/FOXP3 expression, predicts the outcome of immunotherapy with the CD19directed BITE blinatumomab [175]. Blinatumomab responders average $4.82 \%$ Tregs (CI: $1.79-8.34 \%$ ) in PB, whereas non-responders demonstrated $10.25 \%$ Tregs 
(CI: 3.36-65.9\%). Enumeration of Treg identifies $r / r$ ALL patients with a high response rate to blinatumomab. Therapeutic removal of Tregs may convert blinatumomab non-responders to responders [175].

The efficacy of daratumumab depends partially on CD38 expression on MM cells and all-trans retinoic acid (ATRA) upregulates CD38 expression to revert daratumumab-resistance ex vivo. A phase 1/2 study (NCT02751255) evaluated the efficacy of daratumumab combined with ATRA in daratumumab-refractory MM. Patients that previously achieved at least a partial response or minimal response/stable disease with prior daratumumab monotherapy had a significantly longer PFS compared with patients who immediately progressed on daratumumab as single agent (median PFS 3.4 and 2.8 vs. 1.3 months). Addition of ATRA and re-intensification of daratumumab had limited activity in patients with daratumumab-refractory MM, which may be explained by transient upregulation of CD38 [176].

Cell surface expression of the orphan $G$ protein-coupled receptor, GPRC5D, is significantly greater on MM cells, compared with normal PCs, which renders it a promising target for immunotherapy. The bispecific $\mathrm{Ab}$, talquetamab, effectively targets and kills GPRC5D + MM cells in the presence of $\mathrm{T}$ cells from healthy donors as well as heavily pre-treated patients (Fig. 4). Direct contact with BMSCs impaired the efficacy of talquetamab, while combination with daratumumab or Pom enhanced talquetamab-mediated lysis of primary MM cells [90]. Residual immature, myeloma cells within BM increase TAMS, Tregs, memory B cells and reduce PFS and OS in MM independent of cytogenetics, disease status and transplant-eligibility. Therefore, immune reconstitution in MRD negative patients may increase

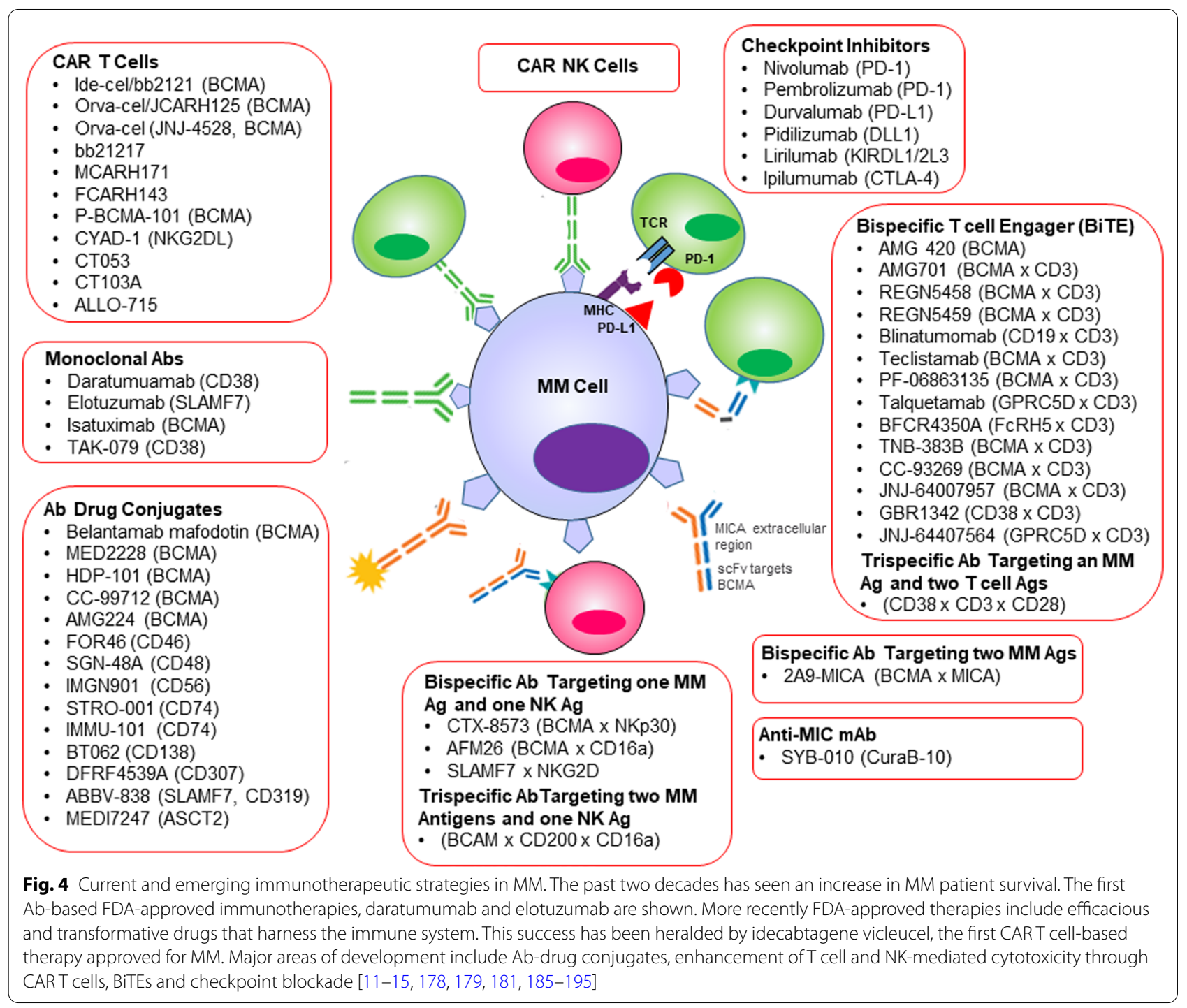


disease-free survival and should also be considered as a treatment strategy $[47,177]$.

\section{Strategies to overcome immune escape in MM}

CAR T, CAR NK cells, Ab drug conjugates, and checkpoint inhibitors have been tested in clinical trials or are in development to treat MM (Fig. 4). BiTE therapy is an immunotherapy that works by serially killing tumor cells by placing them in proximity to $\mathrm{T}$ cells. The anti-CD19 X anti-CD3 drug, blinatumomab (Blincyto) (Fig. 4). CTX8573 is a first-in-class, common light chain-based NKp30 $\mathrm{x}$ BCMA bispecific $\mathrm{Ab}$ that targets $\mathrm{BCMA}+$ plasma cells and potently recruits and activates innate cells through engagement of the NKp30, as well as the activating receptor CD16a through an intact Fc. Compared to mAbs that only engage CD16a, the NKp30 bispecific platform increases ADCC potency more than 100-fold, and maintains activity in the context of CD16a downregulation (Fig. 4).

Bispecific Abs have been engineered in $>50$ different formats, including dual-affinity retargeting proteins (Fig. 4). Recombinant bispecific proteins have been engineered to simultaneously bind (at least) two distinct antigens and CARs facilitate $\mathrm{T}$ and NK cell mediated killing of malignant cells by redirecting autologous CTLs to cell-surface tumor antigens. Importantly, BiTE and CAR $\mathrm{T}$ approaches are independent of endogenous TCR specificity and also independent of MHC specificity on myeloma cells. Recent clinical studies have benefitted from more efficacious immunotherapeutic agents and treatment strategies and yield improved outcomes. Despite these advances, the efficacy of most cancer immunotherapies has been modest. A recurring scenario is that therapeutic maneuvers initially lead to measurable anti-myeloma clinical responses but ultimately failed to improve OS. Immunotherapeutics have been developed that alleviate immunosuppression, e.g., IMiDs and immune checkpoint inhibitors, target highly selective antigens in the form of mAbs that stimulate immune cells to selectively kill malignant cells, e.g., CAR T cells, BiTEs [16, 178-181].

Strategies to enhance the priming phase by loading DC ex vivo or in vivo with tumor antigens, peptide- or DNA-vaccines, or TLR agonists are in development [181, 182]. Restoring or forcing antigen presentation by $\mathrm{MM}$ cells themselves represents an alternative to DC-based therapies to enhance priming. Tumor cells are more numerous than DCs in BM and could directly present their own endogenous antigens, without the need for cross-presentation by DCs. Tumors evade immunosurveillance through shedding the MHC class I chain-related protein A and B (MICA/B) [29]. MICA/B function as ligands for NKG2D, an activating receptor on
$\mathrm{NK}$ and T cells. Shedding reduces MICA/B levels on MM cells, masks the NKG2D receptor and impairs tumor recognition [102]. Tumor-derived soluble NKG2D ligands are associated with poor clinical responses to PD1/ PD-L1 blockade therapy [183]. SYB-010 is a first-in-class, immune stimulatory $\mathrm{mAb}$ that targets tumor-released soluble MICA/B (sMIC) (Fig. 4).

In the related $B$ cell malignancy acute lymphoblastic leukemia (ALL), primary resistance to CD19-directed CAR $T$ cell therapy (CART19) occurs in $10-20 \%$ of patients and CART19 resistance is a significant barrier to treatment [184]. A genome-wide loss-of function screen, found that impaired death receptor signaling in ALL led to rapidly progressive disease despite CART19 treatment. The effect was mediated by an inherent resistance to $\mathrm{T}$ cell cytotoxicity that permitted antigen persistence and was magnified by CAR T cell impairment. Notably, the findings were validated using samples from two CAR $T$ cell clinical trials, where the authors found that reduced expression of death receptor genes was associated with worse OS and reduced T cell fitness.

\section{Conclusions}

MM remains an incurable malignancy despite great advances in therapy. Residual disease persists and reaches an equilibrium with host immunity that results in either sustained remission or disease recurrence. During this equilibrium, chemotherapy, immune adjuvants, and consequences of therapy-induced responses, e.g., proinflammatory cytokines, shift the balance in either direction. Novel therapies must balance immune-enhancing effects while minimizing side effects. IMiDs, PI's, mAbs, checkpoint inhibitors, NK and T cell-based therapies have the potential to reverse immunosuppression and restore effective immunosurveillance. Since the pathology of MM includes a critical interaction between tumor cells and the TME, targeting this interaction should provide clinical benefit. Most studies thus far have been performed with RRMM, however, it is not known if patients would benefit from strategies at early disease stages. Enhanced knowledge of tumor immunity should help design strategies that improve OS.

\section{Abbreviations}

ADCC: Antibody-dependent cellular cytotoxicity; ALL: Acute lymphoblastic leukemia; ANC: Absolute neutrophil count; APC: Antigen-presenting cell; APM: Antigen presenting machinery; APRIL: A proliferation-inducing ligand; ASCT: Autologous stem cell transplantation; ATRA: All-trans retinoic acis; $\beta 2 \mathrm{~m}$ : B2-Microglobulin; BiTEs: Bispecific T-cell engagers; BM: Bone marrow; BMSC: Bone marrow stromal cell; BMMSC: Bone marrow mesenchymal stromal cells; $B$ reg: Regulatory B cell; CAR: Chimeric antigen receptor; CART19: CD19directed CART cell therapy; CD: Cluster of differentiation; CR: Complete remission; CTL: Cytotoxic T lymphocyte; DC: Dendritic cell; DNA: Deoxyribonucleic acid; DNAM-1: DNA accessory molecule 1; ER: Endoplasmic reticulum; EV: Extracellular vesicle; FGF-2: Basic fibroblast growth factor; GABARAP: 
Gamma-aminobutyric acid receptor-associated protein; G-MDSC: Granulocytic myeloid-derived suppressor cell; HDN: High density neutrophil; HIF-1: Hypoxia-inducible factor 1; HLA: Human leukocyte antigen; ICD: Immunogenic cell death; ICOSL: Inducible T cell co-stimulator ligand; IDO: Indolamine dioxygenase; IFN-ү: Interferon gamma; IL: Interleukin; IMiDs: Immunomodulatory agents, immunomodulatory drugs; iTreg: Foxp3-positive regulatory $T$ cell; mAb: Monoclonal antibody; mRNA: Messenger ribonucleic acid; MAPK: Mitogen-activated protein kinase; MDSC: Myeloid-derived suppressor cell; MGUS: Monoclonal gammopathy of unknown significance; MHC: Major histocompatibility complex; MICA: Major histocompatibility complex class I related chain A; MICB: Major histocompatibility complex class I related chain B; MM: Multiple myeloma; MRD: Minimal residual disease; Mo-MDSC: Monocytic myeloid-derived suppressor cell; NCR: Natural cytotoxicity receptor; NCT: National clinical trial; NDMM: Newly diagnosed multiple myeloma; NF-kB: NFkappa B; NK: Natural killer; NO: Nitric oxide; NS-SNV: Non-synonymous single nucleotide variation; OS: Overall survival; PB: Peripheral blood; PC: Plasma cell; PD-1: Programmed cell death protein 1; PD-L1: Programmed cell death ligand 1; PFS: Progression-free survival; PI: Proteasome inhibitors; PMN: Polymorphonuclear; Pom: Pomalidomide; ROR: RAR-related orphan receptor; ROS: Reactive oxygen species; RR: Relapsed and/or refractory; SEER: Surveillance, epidemiology and end results; SMM: Smoldering multiple myeloma; SMIC: Soluble MICA or MICB; TAA: Tumor-associated antigens; TAP: Transporter associated with antigen processing; TCR: $T$ cell receptor; TGF- $\beta$ : Transforming growth factor beta; TGF-BRI: Transforming growth factor beta type I receptor; TIL: Tumorinfiltrating lymphocyte; TLR: Toll-like receptor; TME: Tumor microenvironment; TNF: Tumor necrosis factor; Treg: Regulatory T cell; VEGF: Vascular endothelial growth factor; WGS: Whole genome sequencing.

\section{Acknowledgements}

Not applicable.

\section{Authors' contributions}

MS and JJD wrote the initial draft of the manuscript. All authors edited the manuscript. All authors read and approved the final version of the manuscript.

\section{Funding}

Research was supported by NIH R01 (5R01Al139141), the University Hospitals Cleveland Medical Center/Seidman Cancer Center, the Vinney Foundation and the Case Comprehensive Cancer Center (to JJD).

\section{Availability of data and materials}

Not applicable.

\section{Declarations}

\section{Ethics approval and consent to participate}

Not applicable.

\section{Consent for publication}

Not applicable.

\section{Competing interests}

The authors declare that they have no competing interests.

\section{Author details}

${ }^{1}$ Seidman Cancer Center, University Hospitals, Cleveland, OH, USA. ${ }^{2}$ Department of Biochemistry, Case Western Reserve University, Cleveland, $\mathrm{OH}, \mathrm{USA}$. ${ }^{3}$ Case Comprehensive Cancer Center, Hematopoietic and Immune Cancer Biology Program, Cleveland, $\mathrm{OH}, \mathrm{USA}$.

Received: 20 December 2021 Accepted: 3 February 2022 Published online: 16 February 2022

\section{References}

1. Kyle RA, Rajkumar SV. Multiple myeloma. N Engl J Med. 2004;351(18):1860-73.

2. Palumbo A, Anderson K. Multiple myeloma. N Engl J Med. 2011;364(11):1046-60.
3. Raab MS, Podar K, Breitkreutz I, Richardson PG, Anderson KC. Multiple myeloma. Lancet. 2009;374(9686):324-39.

4. Ho M, Patel A, Goh CY, Moscvin M, Zhang L, Bianchi G. Changing paradigms in diagnosis and treatment of monoclonal gammopathy of undetermined significance (MGUS) and smoldering multiple myeloma (SMM). Leukemia. 2020;34(12):3111-25.

5. Ludwig H, Novis Durie S, Meckl A, Hinke A, Durie B. Multiple myeloma incidence and mortality around the globe; interrelations between health access and quality, economic resources, and patient empowerment. Oncologist. 2020;25(9):e1406-13.

6. Brigle K, Rogers B. Pathobiology and diagnosis of multiple myeloma. Semin Oncol Nurs. 2017;33(3):225-36.

7. Hanamura I, Stewart JP, Huang Y, Zhan F, Santra M, Sawyer JR, Hollmig K, Zangarri M, Pineda-Roman M, van Rhee F, et al. Frequent gain of chromosome band 1q21 in plasma-cell dyscrasias detected by fluorescence in situ hybridization: incidence increases from MGUS to relapsed myeloma and is related to prognosis and disease progression following tandem stem-cell transplantation. Blood. 2006;108(5):1724-32.

8. Hemminki K, Forsti A, Houlston R, Sud A. Epidemiology, genetics and treatment of multiple myeloma and precursor diseases. Int J Cancer. 2021;149(12):1980-96.

9. Siegel RL, Miller KD, Jemal A. Cancer statistics, 2020. CA Cancer J Clin. 2020;70(1):7-30.

10. Ghandili S, Weisel KC, Bokemeyer C, Leypoldt LB: current treatment approaches to newly diagnosed multiple myeloma. Oncol Res Treat 2021:1-8.

11. Kawano Y, Moschetta M, Manier S, Glavey S, Gorgun GT, Roccaro AM, Anderson KC, Ghobrial IM. Targeting the bone marrow microenvironment in multiple myeloma. Immunol Rev. 2015;263(1):160-72.

12. George LL, Deshpande SR, Cortese MJ, Kendall EK, Chattaraj A, Shah Z, Zhao J, Anwer F. Emerging targets and cellular therapy for relapsed refractory multiple myeloma: a systematic review. Clin Lymphoma Myeloma Leuk. 2021;21(11):741-51.

13. Franssen LE, Mutis T, Lokhorst HM, van de Donk N. Immunotherapy in myeloma: how far have we come? Ther Adv Hematol. 2019;10:2040620718822660.

14. Shah UA, Mailankody S: Emerging immunotherapies in multiple myeloma. BMJ 2020;370:m3176.

15. Chung $\mathrm{C}$. Role of immunotherapy in targeting the bone marrow microenvironment in multiple myeloma: an evolving therapeutic strategy. Pharmacotherapy. 2017;37(1):129-43.

16. Bozic B, Rutner J, Zheng C, Ruckser R, Selimi F, Racz K, Kocher M, Tatzreiter $\mathrm{G}$, Sebesta $C$. Advances in the treatment of relapsed and refractory multiple myeloma in patients with renal insufficiency: novel agents, immunotherapies and beyond. Cancers (Basel) 2021, 13(20).

17. Rodriguez-Otero P, Paiva B, Engelhardt M, Prosper F, San Miguel JF. Is immunotherapy here to stay in multiple myeloma? Haematologica. 2017;102(3):423-32.

18. Botta C, Mendicino F, Martino EA, Vigna E, Ronchetti D, Correale P, Morabito F, Neri A, Gentile M. Mechanisms of immune evasion in multiple myeloma: open questions and therapeutic opportunities. Cancers (Basel) 2021, 13(13).

19. Rossi M, Botta C, Correale P, Tassone P, Tagliaferri P. Immunologic microenvironment and personalized treatment in multiple myeloma. Expert Opin Biol Ther. 2013;13(Suppl 1):S83-93.

20. Dunn GP, Bruce AT, Ikeda H, Old LJ, Schreiber RD. Cancer immunoediting: from immunosurveillance to tumor escape. Nat Immunol. 2002;3(11):991-8

21. O'Sullivan T, Saddawi-Konefka R, Vermi W, Koebel CM, Arthur C, White JM, Uppaluri R, Andrews DM, Ngiow SF, Teng MW, et al. Cancer immunoediting by the innate immune system in the absence of adaptive immunity. J Exp Med. 2012;209(10):1869-82.

22. Schreiber RD, Old LJ, Smyth MJ. Cancer immunoediting: integrating immunity's roles in cancer suppression and promotion. Science. 2011;331(6024):1565-70.

23. Mittal D, Gubin MM, Schreiber RD, Smyth MJ. New insights into cancer immunoediting and its three component phases-elimination, equilibrium and escape. Curr Opin Immunol. 2014;27:16-25.

24. Nakamura K, Smyth MJ, Martinet L. Cancer immunoediting and immune dysregulation in multiple myeloma. Blood. 2020;136(24):2731-40. 
25. Dunn GP, Old LJ, Schreiber RD. The three Es of cancer immunoediting Annu Rev Immunol. 2004:22:329-60.

26. Bruttel VS, Wischhusen J. Cancer stem cell immunology: key to understanding tumorigenesis and tumor immune escape? Front Immunol. 2014;5:360.

27. Han BS, Ji S, Woo S, Lee JH, Sin JI. Regulation of the translation activity of antigen-specific mRNA is responsible for antigen loss and tumor immune escape in a HER2-expressing tumor model. Sci Rep. 2019:9(1):2855.

28. Beatty GL, Gladney WL. Immune escape mechanisms as a guide for cancer immunotherapy. Clin Cancer Res. 2015;21(4):687-92.

29. Dhatchinamoorthy K, Colbert JD, Rock KL. Cancer immune evasion through loss of MHC Class I antigen presentation. Front Immunol 2021, 12:636568.

30. Vyas M, Muller R, Pogge von Strandmann E. antigen loss variants: catching hold of escaping foes. Front Immunol 2017, 8:175.

31. Samur MK, Fulciniti M, Aktas Samur A, Bazarbachi AH, Tai YT, Prabhala R, Alonso A, Sperling AS, Campbell T, Petrocca F, et al. Biallelic loss of $B C M A$ as a resistance mechanism to CART cell therapy in a patient with multiple myeloma. Nat Commun. 2021:12(1):868.

32. Ise M, Matsubayashi K, Tsujimura H, Kumagai K. Loss of CD38 expression in relapsed refractory multiple myeloma. Clin Lymphoma Myeloma Leuk. 2016;16(5):e59-64

33. Gulla A, Morelli E, Samur MK, Botta C, Johnstone M, Bianchi G, Fulciniti M, Yamamoto L, Prabhala R, Wen K, et al. Gabarap loss mediates immune escape in high risk multiple myeloma. Blood. 2021;138(Supplement 1):891-891.

34. Lozano E, DiazT, Mena MP, Sune G, Calvo X, Calderon M, Perez-Amill L, Rodriguez $\mathrm{V}$, Perez-Galan P, Roue $\mathrm{G}$, et al. Loss of the immune checkpoint CD85j/LILRB1 on malignant plasma cells contributes to immune escape in multiple myeloma. J Immunol. 2018;200(8):2581-91.

35. Ryu D, Kim SJ, Hong Y, Jo A, Kim N, Kim HJ, Lee HO, Kim K, Park WY. Alterations in the transcriptional programs of myeloma cells and the microenvironment during extramedullary progression affect proliferation and immune evasion. Clin Cancer Res. 2020;26(4):935-44.

36. Racanelli V, Leone P, Frassanito MA, Brunetti C, Perosa F, Ferrone S, Dammacco F. Alterations in the antigen processing-presenting machinery of transformed plasma cells are associated with reduced recognition by CD8+ T cells and characterize the progression of MGUS to multiple myeloma. Blood. 2010;115(6):1185-93.

37. Leone P, Shin EC, Perosa F, Vacca A, Dammacco F, Racanelli V. MHC class I antigen processing and presenting machinery: organization, function, and defects in tumor cells. J Natl Cancer Inst. 2013;105(16):1172-87.

38. Obeid M, Tesniere A, Ghiringhelli F, Fimia GM, Apetoh L, Perfettini JL, Castedo M, Mignot G, Panaretakis T, Casares N, et al. Calreticulin exposure dictates the immunogenicity of cancer cell death. Nat Med. 2007;13(1):54-61.

39. Basu S, Binder RJ, Ramalingam T, Srivastava PK. CD91 is a common receptor for heat shock proteins gp96, hsp90, hsp70, and calreticulin. Immunity. 2001;14(3):303-13.

40. Fonseca R, Bailey RJ, Ahmann GJ, Rajkumar SV, Hoyer JD, Lust JA Kyle RA, Gertz MA, Greipp PR, Dewald GW. Genomic abnormalities in monoclonal gammopathy of undetermined significance. Blood. 2002;100(4):1417-24.

41. Kim M, Ju YS, Lee EJ, Kang HJ, Kim HS, Cho HC, Kim HJ, Kim JA, Lee DS, Lee YK. Abnormalities in chromosomes 1q and 13 independently correlate with factors of poor prognosis in multiple myeloma. Ann Lab Med. 2016;36(6):573-82.

42. Pawlyn C, Morgan GJ. Evolutionary biology of high-risk multiple myeloma. Nat Rev Cancer. 2017;17(9):543-56.

43. Walker BA, Wardell CP, Melchor L, Brioli A, Johnson DC, Kaiser MF, Mirabella F, Lopez-Corral L, Humphray S, Murray L, et al. Intraclonal heterogeneity is a critical early event in the development of myeloma and precedes the development of clinical symptoms. Leukemia. 2014;28(2):384-90.

44. Da Via MC, Dietrich O, Truger M, Arampatzi P, Duell J, Heidemeier A, Zhou X, Danhof S, Kraus S, Chatterjee M, et al. Homozygous BCMA gene deletion in response to anti-BCMA CART cells in a patient with multiple myeloma. Nat Med. 2021;27(4):616-9.

45. Truger MS, Duell J, Zhou X, Heimeshoff L, Ruckdeschel A, John M, Riedel A, Huper S, Peter J, Walter W, et al. Single- and double-hit events in genes encoding immune targets before and after T cell-engaging antibody therapy in MM. Blood Adv. 2021:5(19):3794-8.

46. Maity R, Benaoudia S, Zemp F, Lee H, Barakat E, Leblay N, Ahn S, Mahoney D, Neri P, Bahlis NJ. A BCL2L1 armoured BCMA targeting CAR $T$ cell to overcome exhaustion and enhance persistence in multiple myeloma. Blood. 2021;138(Supplement 1):327-327.

47. Coffey DG, Maura F, Gonzalez-Kozlova E, Diaz-Mejia3 J, Luo P, Zhang Y, XuY, Warren EH, Smith EL, Cho HJ et al. Normalization of the immune microenvironment during Lenalidomide maintenance is associated with sustained MRD negativity in patients with multiple myeloma. Blood 2021, 138(Supplement 1):329-329.

48. Kumar S, Kimlinger T, Morice W. Immunophenotyping in multiple myeloma and related plasma cell disorders. Best Pract Res Clin Haematol. 2010;23(3):433-51.

49. Costa F, Das R, Kini Bailur J, Dhodapkar K, Dhodapkar MV. Checkpoint inhibition in myeloma: opportunities and challenges. Front Immunol. 2018;9:2204.

50. Dwivedi S, Rendon-Huerta EP, Ortiz-Navarrete V, Montano LF. CD38 and regulation of the immune response cells in cancer. J Oncol. 2021;2021:6630295.

51. Spisek R, Kukreja A, Chen LC, Matthews P, Mazumder A, Vesole D, Jagannath S, Zebroski HA, Simpson AJ, Ritter G, et al. Frequent and specific immunity to the embryonal stem cell-associated antigen SOX2 in patients with monoclonal gammopathy. J Exp Med. 2007;204(4):831-40.

52. Carbone E, Neri P, Mesuraca M, Fulciniti MT, Otsuki T, Pende D, Groh V, Spies T, Pollio G, Cosman D, et al. HLA class I, NKG2D, and natural cytotoxicity receptors regulate multiple myeloma cell recognition by natural killer cells. Blood. 2005;105(1):251-8.

53. Robbins PD, Morelli AE. Regulation of immune responses by extracellular vesicles. Nat Rev Immunol. 2014:14(3):195-208.

54. Zhou X, Xie F, Wang L, Zhang L, Zhang S, Fang M, Zhou F. The function and clinical application of extracellular vesicles in innate immune regulation. Cell Mol Immunol. 2020;17(4):323-34.

55. Veerman RE, Gucluler Akpinar G, Eldh M, Gabrielsson S. Immune cellderived extracellular vesicles - functions and therapeutic applications. Trends Mol Med. 2019;25(5):382-94

56. Domenis R, Cesselli D, Toffoletto B, Bourkoula E, Caponnetto F, Manini I, Beltrami AP, lus T, Skrap M, Di Loreto C et al: Systemic t cells immunosuppression of glioma stem cell-derived exosomes is mediated by monocytic myeloid-derived suppressor cells. PLoS One 2017, 12(1):e0169932.

57. Pritchard A, Tousif S, Wang Y, Hough K, Khan S, Strenkowski J, Chacko BK, Darley-Usmar VM, Deshane JS. Lung tumor cell-derived exosomes promote M2 macrophage polarization. Cells 2020, 9(5).

58. Umezu T, Tadokoro H, Azuma K, Yoshizawa S, Ohyashiki K, Ohyashiki $\mathrm{JH}$. Exosomal miR-135b shed from hypoxic multiple myeloma cells enhances angiogenesis by targeting factor-inhibiting HIF-1. Blood. 2014:124(25):3748-57.

59. Tian X, Shen H, Li Z, Wang T, Wang S. Tumor-derived exosomes, myeloid-derived suppressor cells, and tumor microenvironment. J Hematol Oncol. 2019;12(1):84.

60. Sanjabi S, Zenewicz LA, Kamanaka M, Flavell RA. Anti-inflammatory and pro-inflammatory roles of TGF-beta, IL-10, and IL-22 in immunity and autoimmunity. Curr Opin Pharmacol. 2009:9(4):447-53.

61. Lu A, Pallero MA, Lei W, Hong H, Yang Y, Suto MJ, Murphy-Ullrich JE. Inhibition of transforming growth factor-beta activation diminishes tumor progression and osteolytic bone disease in mouse models of multiple myeloma. Am J Pathol. 2016;186(3):678-90.

62. Fu S, Zhang N, Yopp AC, Chen D, Mao M, Chen D, Zhang H, Ding Y, Bromberg JS. TGF-beta induces Foxp3 + T-regulatory cells from CD4 + CD25 - precursors. Am J Transpl. 2004;4(10):1614-27.

63. Zhang $\mathrm{S}$. The role of transforming growth factor beta in $\mathrm{T}$ helper 17 differentiation. Immunology. 2018;155(1):24-35.

64. Malek E, Hwang S, de Lima M, Caimi P, Gallogly M, Metheny LL, Otegbeye F, Tomlinson BK, Boughan KM, Cooper B, Driscoll JJ, Letterio J. Preclinical studies and phase I trial of vactosertib in combinationwith pomalidomide in relapsed multiple myeloma: a corticosteroid-free approach by targeting TGF- $\beta$ signaling pathway. Blood. 2019;134(suppl. 1):3232. 
65. Kim BG, Malek E, Choi SH, Ignatz-Hoover JJ, Driscoll JJ. Novel therapies emerging in oncology to target the TGF-beta pathway. J Hematol Oncol. 2021;14(1):55.

66. Malek E, Caimi P, Metheny LL, Tomlinson BK, Cooper BW, Boughan K, Otegbeye F, Gallogly M, Driscoll JJ, de Lima M. Phase Ib trial of vactosertib in combination with pomalidomide in relapsed multiple myeloma: a corticosteroid-free approach by targeting TGF- $\beta$ signaling pathway. J Clin Oncol. 2021;39(15 suppl.):8039.

67. Basler M, Groettrup M. Recent insights how combined inhibition of immuno/proteasome subunits enables therapeutic efficacy. Genes Immun. 2020;21(5):273-87.

68. Ritz U, Seliger B. The transporter associated with antigen processing (TAP): structural integrity, expression, function, and its clinical relevance. Mol Med. 2001;7(3):149-58.

69. Lankat-Buttgereit B, Tampe R. The transporter associated with antigen processing TAP: structure and function. FEBS Lett. 1999;464(3):108-12.

70. Seliger B, Maeurer MJ, Ferrone S. Antigen-processing machinery breakdown and tumor growth. Immunol Today. 2000;21(9):455-64.

71. Guillerey C, Nakamura K, Vuckovic S, Hill GR, Smyth MJ. Immune responses in multiple myeloma: role of the natural immune surveillance and potential of immunotherapies. Cell Mol Life Sci. 2016;73(8):1569-89.

72. Cohen AD, Raje N, Fowler JA, Mezzi K, Scott EC, Dhodapkar MV. How to train your T cells: overcoming immune dysfunction in multiple myeloma. Clin Cancer Res. 2020;26(7):1541-54.

73. Moss P, Gillespie G, Frodsham P, Bell J, Reyburn H. Clonal populations of CD4+ and CD8+ T cells in patients with multiple myeloma and paraproteinemia. Blood. 1996;87(8):3297-306.

74. Mariani S, Coscia M, Even J, Peola S, Foglietta M, Boccadoro M, Sbaiz L Restagno G, Pileri A, Massaia M. Severe and long-lasting disruption of T-cell receptor diversity in human myeloma after high-dose chemotherapy and autologous peripheral blood progenitor cell infusion. $\mathrm{Br}$ Haematol. 2001;113(4):1051-9.

75. Halapi E, Werner A, Wahlstrom J, Osterborg A, Jeddi-Tehrani M, Yi Q, Janson $\mathrm{CH}$, Wigzell $\mathrm{H}$, Grunewald J, Mellstedt $\mathrm{H}$. T cell repertoire in patients with multiple myeloma and monoclonal gammopathy of undetermined significance: clonal CD8 $+T$ cell expansions are found preferentially in patients with a low tumor burden. Eur J Immunol. 1997;27(9):2245-52

76. San Miguel JF, Gonzalez M, Gascon A, Moro MJ, Hernandez JM, Ortega F, Jimenez R, Guerras L, Romero M, Casanova F et al. Lymphoid subsets and prognostic factors in multiple myeloma. Cooperative Group for the Study of Monoclonal Gammopathies. Br J Haematol 1992, 80(3):305-9.

77. Mills KH, Cawley JC. Abnormal monoclonal antibody-defined helper/ suppressor T-cell subpopulations in multiple myeloma: relationship to treatment and clinical stage. Br J Haematol. 1983;53(2):271-5.

78. Gu Y, Jin Y, Ding J, Yujie W, Shi Q, Qu X, Zhao S, Li J, Lijuan C. Low absolute CD4(+) T cell counts in peripheral blood predict poor prognosis in patients with newly diagnosed multiple myeloma. Leuk Lymphoma. 2020;61(8):1869-76

79. Wherry EJ.T cell exhaustion. Nat Immunol. 2011;12(6):492-9.

80. Suen H, Brown R, Yang S, Weatherburn C, Ho PJ, Woodland N, Nassif N, Barbaro P, Bryant C, Hart D, et al. Multiple myeloma causes clonal T-cell immunosenescence: identification of potential novel targets for promoting tumour immunity and implications for checkpoint blockade. Leukemia. 2016;30(8):1716-24.

81. Frassanito MA, Cusmai A, Dammacco F. Deregulated cytokine network and defective Th1 immune response in multiple myeloma. Clin Exp Immunol. 2001;125(2):190-7.

82. Sharma A, Khan R, Joshi S, Kumar L, Sharma M. Dysregulation in T helper $1 / T$ helper 2 cytokine ratios in patients with multiple myeloma. Leuk Lymphoma. 2010:51(5):920-7.

83. Ogawara H, Handa H, Yamazaki T, Toda T, Yoshida K, Nishimoto N, Alma'Quol WH, Kaneko Y, Matsushima T, Tsukamoto N, et al. High Th1/Th2 ratio in patients with multiple myeloma. Leuk Res. 2005;29(2):135-40.

84. Prabhala RH, Neri P, Bae JE, Tassone P, Shammas MA, Allam CK, Daley JF, Chauhan D, Blanchard E, Thatte HS, et al. Dysfunctional T regulatory cells in multiple myeloma. Blood. 2006;107(1):301-4.

85. Beyer M, Kochanek M, Giese T, Endl E, Weihrauch MR, Knolle PA, Classen S, Schultze JL. In vivo peripheral expansion of naive
CD4+CD25high FoxP3 + regulatory T cells in patients with multiple myeloma. Blood. 2006;107(10):3940-9.

86. Braga WM, Atanackovic D, Colleoni GW: The role of regulatory $T$ cells and TH17 cells in multiple myeloma. Clin Dev Immunol 2012, 2012:293479.

87. Giannopoulos K, Kaminska W, Hus I, Dmoszynska A. The frequency of T regulatory cells modulates the survival of multiple myeloma patients: detailed characterisation of immune status in multiple myeloma. Br J Cancer. 2012;106(3):546-52.

88. Vignali DA, Collison LW, Workman CJ. How regulatory T cells work. Nat Rev Immunol. 2008;8(7):523-32.

89. Rosean TR, Tompkins VS, Tricot G, Holman CJ, Olivier AK, Zhan F, Janz S. Preclinical validation of interleukin 6 as a therapeutic target in multiple myeloma. Immunol Res. 2014;59(1-3):188-202.

90. Verkleij CPM, Broekmans MEC, van Duin M, Frerichs KA, Kuiper R, de Jonge AV, Kaiser M, Morgan G, Axel A, Boominathan R, et al. Preclinical activity and determinants of response of the GPRC5DxCD3 bispecific antibody talquetamab in multiple myeloma. Blood Adv. 2021;5(8):2196-215.

91. Prabhala RH, Pelluru D, Fulciniti M, Prabhala HK, Nanjappa P, Song W, Pai C, Amin S, Tai YT, Richardson PG, et al. Elevated IL-17 produced by $\mathrm{TH} 17$ cells promotes myeloma cell growth and inhibits immune function in multiple myeloma. Blood. 2010;115(26):5385-92.

92. Kimura A, Kishimoto T. IL-6: regulator of Treg/Th17 balance. Eur J Immunol. 2010;40(7):1830-5.

93. Brown R, Kabani K, Favaloro J, Yang S, Ho PJ, Gibson J, Fromm P, Suen $\mathrm{H}$, Woodland N, Nassif N, et al. CD86+ or HLA-G+ can be transferred via trogocytosis from myeloma cells to $T$ cells and are associated with poor prognosis. Blood. 2012;120(10):2055-63.

94. Joly $E$, Hudrisier D. What is trogocytosis and what is its purpose? Nat Immunol. 2003:4(9):815.

95. Davis DM. Intercellular transfer of cell-surface proteins is common and can affect many stages of an immune response. Nat Rev Immunol. 2007;7(3):238-43.

96. Brown R, Suen H, Favaloro J, Yang S, Ho PJ, Gibson J, Joshua D. Trogocytosis generates acquired regulatory $T$ cells adding further complexity to the dysfunctional immune response in multiple myeloma. Oncoimmunology. 2012;1(9):1658-60.

97. Gu P, Gao JF, D'Souza CA, Kowalczyk A, Chou KY, Zhang L. Trogocytosis of CD80 and CD86 by induced regulatory T cells. Cell Mol Immunol. 2012;9(2):136-46.

98. Krejcik J, van de Donk N. Trogocytosis represents a novel mechanism of action of daratumumab in multiple myeloma. Oncotarget. 2018:9(72):33621-2.

99. Vivier E, Ugolini S, Blaise D, Chabannon C, Brossay L. Targeting natural killer cells and natural killer T cells in cancer. Nat Rev Immunol. 2012;12(4):239-52.

100. Liu P, Jin Y, Sattar H, Liu H, Xie W, Zhou F. Natural killer cell immunotherapy against multiple myeloma: Progress and possibilities. J Leukoc Biol. 2018;103(5):821-8.

101. Bernal M, Garrido P, Jimenez P, Carretero R, Almagro M, Lopez P, Navarro P, Garrido F, Ruiz-Cabello F. Changes in activatory and inhibitory natural killer (NK) receptors may induce progression to multiple myeloma: implications for tumor evasion of T and NK cells. Hum Immunol. 2009;70(10):854-7.

102. Jinushi M, Vanneman M, Munshi NC, Tai YT, Prabhala RH, Ritz J, Neuberg D, Anderson KC, Carrasco DR, Dranoff G. MHC class I chain-related protein $A$ antibodies and shedding are associated with the progression of multiple myeloma. Proc Natl Acad Sci U S A. 2008;105(4):1285-90

103. Guillerey C, Ferrari de Andrade L, Vuckovic S, Miles K, Ngiow SF, Yong MC, Teng MW, Colonna M, Ritchie DS, Chesi M et al. Immunosurveillance and therapy of multiple myeloma are CD226 dependent. J Clin Invest 2015, 125(7):2904.

104. Sawanobori M, Suzuki K, Nakagawa Y, Inoue Y, Utsuyama M, Hirokawa K. Natural killer cell frequency and serum cytokine levels in monoclonal gammopathies: correlation of bone marrow granular lymphocytes to prognosis. Acta Haematol. 1997;98(3):150-4.

105. Dosani T, Carlsten M, Maric I, Landgren O. The cellular immune system in myelomagenesis: NK cells and T cells in the development of MM and their uses in immunotherapies. Blood Cancer J 2015;5:e321. 
106. von Lilienfeld-Toal M, Frank S, Leyendecker C, Feyler S, Jarmin S, Morgan R, Glasmacher A, Marten A, Schmidt-Wolf IG, Brossart P, et al. Reduced immune effector cell NKG2D expression and increased levels of soluble NKG2D ligands in multiple myeloma may not be causally linked. Cancer Immunol Immunother. 2010;59(6):829-39.

107. Benson DM Jr, Bakan CE, Mishra A, Hofmeister CC, Efebera Y, Becknell B, Baiocchi RA, Zhang J, Yu J, Smith MK, et al. The PD-1/PD-L1 axis modulates the natural killer cell versus multiple myeloma effect: a therapeutic target for CT-011, a novel monoclonal anti-PD-1 antibody. Blood. 2010;116(13):2286-94.

108. Fauriat C, Mallet F, Olive D, Costello RT. Impaired activating receptor expression pattern in natural killer cells from patients with multiple myeloma. Leukemia. 2006;20(4):732-3.

109. Costello RT, Boehrer A, Sanchez C, Mercier D, Baier C, Le Treut T, Sebahoun G. Differential expression of natural killer cell activating receptors in blood versus bone marrow in patients with monoclonal gammopathy. Immunology. 2013;139(3):338-41.

110. Castriconi R, Cantoni C, Della Chiesa M, Vitale M, Marcenaro E, Conte R, Biassoni R, Bottino C, Moretta L, Moretta A. Transforming growth factor beta 1 inhibits expression of NKp30 and NKG2D receptors: consequences for the NK-mediated killing of dendritic cells. Proc Natl Acad Sci USA. 2003;100(7):4120-5.

111. Lee JC, Lee KM, Kim DW, Heo DS. Elevated TGF-beta1 secretion and down-modulation of NKG2D underlies impaired NK cytotoxicity in cancer patients. J Immunol. 2004;172(12):7335-40.

112. Fiegler N, Textor S, Arnold A, Rolle A, Oehme I, Breuhahn K, Moldenhauer G, Witzens-Harig M, Cerwenka A. Downregulation of the activating NKp30 ligand B7-H6 by HDAC inhibitors impairs tumor cell recognition by NK cells. Blood. 2013;122(5):684-93.

113. Perez-Andres M, Almeida J, Martin-Ayuso M, Moro MJ, Martin-Nunez G, Galende J, Borrego D, Rodriguez MJ, Ortega F, Hernandez J, et al. Clonal plasma cells from monoclonal gammopathy of undetermined significance, multiple myeloma and plasma cell leukemia show different expression profiles of molecules involved in the interaction with the immunological bone marrow microenvironment. Leukemia. 2005;19(3):449-55.

114. Yang Y, Liu Z, Wang H, Zhang G. HLA-E binding peptide as a potential therapeutic candidate for high-risk multiple myeloma. Front Oncol 2021 11:670673.

115. Cai X, Zhang L, Wei W. Regulatory B cells in inflammatory diseases and tumor. Int Immunopharmacol. 2019;67:281-6.

116. Sarvaria A, Madrigal JA, Saudemont A. B cell regulation in cancer and anti-tumor immunity. Cell Mol Immunol. 2017;14(8):662-74.

117. Mauri C, Menon M. The expanding family of regulatory B cells. Int Immunol. 2015;27(10):479-86.

118. Xiao X, Lao XM, Chen MM, Liu RX, Wei Y, Ouyang FZ, Chen DP, Zhao XY, Zhao Q, Li XF, et al. PD-1 hi identifies a novel regulatory B-cell population in human hepatoma that promotes disease progression. Cancer Discov. 2016;6(5):546-59.

119. Rosser EC, Mauri C. Regulatory B cells: origin, phenotype, and function. Immunity. 2015;42(4):607-12.

120. Flores-Borja F, Bosma A, Ng D, Reddy V, Ehrenstein MR, Isenberg DA, Mauri C. CD19+CD24hiCD38hi B cells maintain regulatory T cells while limiting TH1 and TH17 differentiation. Sci Trans/ Med 2013, 5(173):173ra123.

121. Ray A, Basu S, Williams CB, Salzman NH, Dittel BN. A novel IL-10-independent regulatory role for $B$ cells in suppressing autoimmunity by maintenance of regulatory T cells via GITR ligand. J Immunol. 2012;188(7):3188-98.

122. Blair PA, Norena LY, Flores-Borja F, Rawlings DJ, Isenberg DA, Ehrenstein MR, Mauri C. CD19(+)CD24(hi)CD38(hi) B cells exhibit regulatory capacity in healthy individuals but are functionally impaired in systemic Lupus Erythematosus patients. Immunity. 2010;32(1):129-40.

123. Zhang L, Tai YT, Ho M, Xing L, Chauhan D, Gang A, Qiu L, Anderson KC Regulatory $B$ cell-myeloma cell interaction confers immunosuppression and promotes their survival in the bone marrow milieu. Blood Cancer J 2017, 7(3):e547.

124. Bartosinska J, Purkot J, Karczmarczyk A, Chojnacki M, Zaleska J, Wlasiuk P, Grzasko N, Morawska M, Walter-Croneck A, UsnarskaZubkiewicz L et al. Differential Function of a Novel Population of the
CD19+CD24hiCD38hi Bregs in Psoriasis and Multiple Myeloma. Cells 2021, 10(2).

125. Wang S, Yang J, Qian J, Wezeman M, Kwak LW, Yi Q. Tumor evasion of the immune system: inhibiting p38 MAPK signaling restores the function of dendritic cells in multiple myeloma. Blood. 2006;107(6):2432-9.

126. Ratta M, Fagnoni F, Curti A, Vescovini R, Sansoni P, Oliviero B, Fogli $M$, Ferri $E$, Della Cuna GR, Tura $S$, et al. Dendritic cells are functionally defective in multiple myeloma: the role of interleukin-6. Blood. 2002:100(1):230-7.

127. Brown RD, Pope B, Murray A, Esdale W, Sze DM, Gibson J, Ho PJ, Hart $D$, Joshua D. Dendritic cells from patients with myeloma are numerically normal but functionally defective as they fail to up-regulate CD80 (B7-1) expression after huCD40LT stimulation because of inhibition by transforming growth factor-beta1 and interleukin-10. Blood. 2001;98(10):2992-8.

128. Leone P, Berardi S, Frassanito MA, Ria R, De Re V, Cicco S, Battaglia S, Ditonno P, Dammacco F, Vacca A, et al. Dendritic cells accumulate in the bone marrow of myeloma patients where they protect tumor plasma cells from CD8+ T-cell killing. Blood. 2015;126(12):1443-51.

129. Banerjee DK, Dhodapkar MV, Matayeva E, Steinman RM, Dhodapkar KM. Expansion of FOXP3high regulatory T cells by human dendritic cells (DCs) in vitro and after injection of cytokine-matured DCs in myeloma patients. Blood. 2006;108(8):2655-61.

130. Noy R, Pollard JW. Tumor-associated macrophages: from mechanisms to therapy. Immunity. 2014;41(1):49-61.

131. Cook J, Hagemann T. Tumour-associated macrophages and cancer. Curr Opin Pharmacol. 2013;13(4):595-601.

132. Qian BZ, Li J, Zhang H, Kitamura T, Zhang J, Campion LR, Kaiser EA, Snyder LA, Pollard JW. CCL2 recruits inflammatory monocytes to facilitate breast-tumour metastasis. Nature. 2011;475(7355):222-5.

133. Sica A, Mantovani A. Macrophage plasticity and polarization: in vivo veritas. J Clin Invest. 2012;122(3):787-95.

134. Ribatti D, Nico B, Vacca A. Importance of the bone marrow microenvironment in inducing the angiogenic response in multiple myeloma. Oncogene. 2006;25(31):4257-66.

135. Khalife J, Ghose J, Martella M, Viola D, Rocci A, Troadec E, Terrazas C, Satoskar AR, Gunes EG, Dona A et al. MiR-16 regulates crosstalk in NFkappaB tolerogenic inflammatory signaling between myeloma cells and bone marrow macrophages. JCI Insight 2019, 4(21).

136. Hope C, Ollar SJ, Heninger E, Hebron E, Jensen JL, Kim J, Maroulakou I, Miyamoto S, Leith C, Yang DT, et al. TPL2 kinase regulates the inflammatory milieu of the myeloma niche. Blood. 2014;123(21):3305-15.

137. Zheng Y, Cai Z, Wang S, Zhang X, Qian J, Hong S, Li H, Wang M, Yang J, Yi Q. Macrophages are an abundant component of myeloma microenvironment and protect myeloma cells from chemotherapy drug-induced apoptosis. Blood. 2009:114(17):3625-8.

138. Zheng Y, Yang J, Qian J, Qiu P, Hanabuchi S, Lu Y, Wang Z, Liu Z, Li H, He J, et al. PSGL-1/selectin and ICAM-1/CD18 interactions are involved in macrophage-induced drug resistance in myeloma. Leukemia. 2013;27(3):702-10.

139. Costes V, Portier M, Lu ZY, Rossi JF, Bataille R, Klein B. Interleukin-1 in multiple myeloma: producer cells and their role in the control of IL-6 production. Br J Haematol. 1998;103(4):1152-60.

140. Otsuki T, Yata K, Sakaguchi H, Uno M, Fujii T, Wada H, Sugihara T, Ueki A. IL-10 in myeloma cells. Leuk Lymphoma. 2002:43(5):969-74.

141. Scavelli C, Nico B, Cirulli T, Ria R, Di Pietro G, Mangieri D, Bacigalupo A, Mangialardi G, Coluccia AM, Caravita T, et al. Vasculogenic mimicry by bone marrow macrophages in patients with multiple myeloma. Oncogene. 2008;27(5):663-74.

142. Almand B, Clark Jl, Nikitina E, van Beynen J, English NR, Knight SC, Carbone DP, Gabrilovich DI. Increased production of immature myeloid cells in cancer patients: a mechanism of immunosuppression in cancer. J Immunol. 2001;166(1):678-89.

143. Diaz-Montero CM, Salem ML, Nishimura MI, Garrett-Mayer E, Cole DJ, Montero AJ. Increased circulating myeloid-derived suppressor cells correlate with clinical cancer stage, metastatic tumor burden, and doxorubicin-cyclophosphamide chemotherapy. Cancer Immunol Immunother. 2009:58(1):49-59.

144. Gorgun GT, Whitehill G, Anderson JL, Hideshima T, Maguire C, Laubach J, Raje N, Munshi NC, Richardson PG, Anderson KC. Tumor-promoting 
immune-suppressive myeloid-derived suppressor cells in the multiple myeloma microenvironment in humans. Blood. 2013;121(15):2975-87.

145. Gabrilovich DI, Ostrand-Rosenberg S, Bronte V. Coordinated regulation of myeloid cells by tumours. Nat Rev Immunol. 2012;12(4):253-68.

146. Talmadge JE, Gabrilovich DI. History of myeloid-derived suppressor cells. Nat Rev Cancer. 2013;13(10):739-52.

147. Veglia F, Sanseviero E, Gabrilovich DI. Myeloid-derived suppressor cells in the era of increasing myeloid cell diversity. Nat Rev Immunol. 2021;21(8):485-98.

148. Bronte V, Brandau S, Chen SH, Colombo MP, Frey AB, Greten TF, Mandruzzato S, Murray PJ, Ochoa A, Ostrand-Rosenberg S, et al. Recommendations for myeloid-derived suppressor cell nomenclature and characterization standards. Nat Commun. 2016;7:12150.

149. Favaloro J, Liyadipitiya T, Brown R, Yang S, Suen H, Woodland N, Nassif N, Hart D, Fromm P, Weatherburn C, et al. Myeloid derived suppressor cells are numerically, functionally and phenotypically different in patients with multiple myeloma. Leuk Lymphoma. 2014;55(12):2893-900.

150. Brimnes MK, Vangsted AJ, Knudsen LM, Gimsing P, Gang AO, Johnsen $\mathrm{HE}$, Svane IM. Increased level of both CD4+FOXP3+ regulatory T cells and CD14+HLA-DR(-)/low myeloid-derived suppressor cells and decreased level of dendritic cells in patients with multiple myeloma. Scand J Immunol. 2010;72(6):540-7.

151. Wang Z, Zhang L, Wang H, Xiong S, Li Y, Tao Q, Xiao W, Qin H, Wang Y, Zhai Z. Tumor-induced CD14+HLA-DR (-/low) myeloid-derived suppressor cells correlate with tumor progression and outcome of therapy in multiple myeloma patients. Cancer Immunol Immunother 2015;64(3):389-99.

152. Mazzoni A, Bronte V, Visintin A, Spitzer JH, Apolloni E, Serafini P, Zanovello $P$, Segal DM. Myeloid suppressor lines inhibit T cell responses by an NO-dependent mechanism. J Immunol. 2002;168(2):689-95.

153. Hanson EM, Clements VK, Sinha P, Ilkovitch D, Ostrand-Rosenberg S Myeloid-derived suppressor cells down-regulate L-selectin expression on CD4+ and CD8+ T cells. J Immunol. 2009;183(2):937-44.

154. Manjili MH, Wang XY, Abrams S. Evolution of our understanding of myeloid regulatory cells: from MDSCs to Mregs. Front Immunol. 2014;5:303.

155. Li H, Han Y, Guo Q, Zhang M, Cao X. Cancer-expanded myeloid-derived suppressor cells induce anergy of NK cells through membrane-bound TGF-beta 1. J Immunol. 2009;182(1):240-9.

156. Elkabets M, Ribeiro VS, Dinarello CA, Ostrand-Rosenberg S, Di Santo JP, Apte RN, Vosshenrich CA. IL-1 beta regulates a novel myeloid-derived suppressor cell subset that impairs NK cell development and function. Eur J Immunol. 2010;40(12):3347-57.

157. Ostrand-Rosenberg S, Sinha P, Beury DW, Clements VK. Cross-talk between myeloid-derived suppressor cells (MDSC), macrophages, and dendritic cells enhances tumor-induced immune suppression. Semin Cancer Biol. 2012;22(4):275-81.

158. Sinha P, Clements VK, Bunt SK, Albelda SM, Ostrand-Rosenberg S. Cross-talk between myeloid-derived suppressor cells and macrophages subverts tumor immunity toward a type 2 response. J Immunol. 2007;179(2):977-83

159. Karle H, Hansen NE, Plesner T. Neutrophil defect in multiple myeloma. Studies on intraneutrophilic lysozyme in multiple myeloma and malignant lymphoma. Scand J Haematol 1976, 17(1):62-70.

160. Mu S, Ai L, Fan F, Qin Y, Sun C, Hu Y. Prognostic role of neutrophil-tolymphocyte ratio in diffuse large B cell lymphoma patients: an updated dose-response meta-analysis. Cancer Cell Int. 2018;18:119.

161. Romano A, Parrinello NL, Simeon V, Puglisi F, La Cava P, Bellofiore C, Giallongo C, Camiolo G, D'Auria F, Grieco V, et al. High-density neutrophils in MGUS and multiple myeloma are dysfunctional and immunesuppressive due to increased STAT3 downstream signaling. Sci Rep. 2020;10(1):1983

162. Puglisi F, Parrinello NL, Giallongo C, Cambria D, Camiolo G, Bellofiore C, Conticello C, Del Fabro V, Leotta V, Markovic U et al. Plasticity of HighDensity Neutrophils in Multiple Myeloma is Associated with Increased Autophagy Via STAT3. Int J Mol Sci 2019, 20(14).

163. Petersson J, Askman S, Pettersson A, Wichert S, Hellmark T, Johansson ACM, Hansson M. Bone marrow neutrophils of multiple myeloma patients exhibit myeloid-derived suppressor cell activity. J Immunol Res. 2021;2021:6344344

164. Mitsiades CS, Mitsiades NS, Munshi NC, Richardson PG, Anderson $\mathrm{KC}$. The role of the bone microenvironment in the pathophysiology and therapeutic management of multiple myeloma: interplay of growth factors, their receptors and stromal interactions. Eur J Cancer. 2006:42(11):1564-73.

165. Anderson NM, Simon MC. The tumor microenvironment. Curr Biol. 2020;30(16):R921-5.

166. Manier S, Sacco A, Leleu X, Ghobrial IM, Roccaro AM. Bone marrow microenvironment in multiple myeloma progression. J Biomed Biotechnol 2012, 2012:157496.

167. de Jong MME, Kellermayer Z, Papazian N, Tahri S, Hofste Op Bruinink D, Hoogenboezem R, Sanders MA, van de Woestijne PC, Bos PK, Khandanpour $\mathrm{C}$ et al. The multiple myeloma microenvironment is defined by an inflammatory stromal cell landscape. Nat Immunol 2021, 22(6):769-780.

168. Pittari G, Vago L, Festuccia M, Bonini C, Mudawi D, Giaccone L, Bruno B. Restoring natural killer cell immunity against multiple myeloma in the era of new drugs. Front Immunol. 2017;8:1444.

169. Swan D, Lynch K, Gurney M, O'Dwyer M. Current and emerging immunotherapeutic approaches to the treatment of multiple myeloma. Ther Adv Hematol. 2019;10:2040620719854171.

170. Garcia-Ortiz A, Rodriguez-Garcia Y, Encinas J, Maroto-Martin E, Castellano E, Teixido J, Martinez-Lopez J. The role of tumor microenvironment in multiple myeloma development and progression. Cancers (Basel) 2021;13(2).

171. Holthof LC, van der Schans JJ, Katsarou A, Poels R, Gelderloos AT, Drent E, van Hal-van Veen SE, Li F, Zweegman S, van de Donk N, et al. Bone marrow mesenchymal stromal cells can render multiple myeloma cells resistant to cytotoxic machinery of CAR T cells through inhibition of apoptosis. Clin Cancer Res. 2021:27(13):3793-803.

172. Moreaux J, Legouffe E, Jourdan E, Quittet P, Reme T, Lugagne C, Moine P, Rossi JF, Klein B, Tarte K. BAFF and APRIL protect myeloma cells from apoptosis induced by interleukin 6 deprivation and dexamethasone. Blood. 2004;103(8):3148-57.

173. Novak AJ, Darce JR, Arendt BK, Harder B, Henderson K, Kindsvogel W, Gross JA, Greipp PR, Jelinek DF. Expression of BCMA, TACl, and BAFF-R in multiple myeloma: a mechanism for growth and survival. Blood. 2004;103(2):689-94.

174. Wang J, Hendrix A, Hernot S, Lemaire M, De Bruyne E, Van Valckenborgh E, Lahoutte T, De Wever O, Vanderkerken K, Menu E. Bone marrow stromal cell-derived exosomes as communicators in drug resistance in multiple myeloma cells. Blood. 2014;124(4):555-66.

175. Duell J, Dittrich M, Bedke T, Mueller T, Eisele F, Rosenwald A, Rasche L, Hartmann E, Dandekar T, Einsele $H$, et al. Frequency of regulatory $T$ cells determines the outcome of the T-cell-engaging antibody blinatumomab in patients with B-precursor ALL. Leukemia. 2017:31(10):2181-90.

176. Frerichs KA, Minnema MC, Levin MD, Broijl A, Bos GMJ, Kersten MJ Mutis T, Verkleij CPM, Nijhof IS, Maas-Bosman PWC, et al. Efficacy and safety of daratumumab combined with all-trans retinoic acid in relapsed/refractory multiple myeloma. Blood Adv. 2021;5(23):5128-39.

177. Papadimitriou K, Tsakirakis N, Malandrakis P, Vitsos P, Metousis A, Orologas-Stavrou N, Ntanasis-Stathopoulos I, Kanellias N, EleutherakisPapaiakovou E, Pothos P et al. Deep phenotyping reveals distinct immune signatures correlating with prognostication, treatment responses, and MRD status in multiple myeloma. Cancers (Basel). 2020;12(11).

178. Garcia-Guerrero E, Sierro-Martinez B, Perez-Simon JA. Overcoming chimeric antigen receptor (CAR) modified T-cell therapy limitations in multiple myeloma. Front Immunol. 2020;11:1128.

179. Castaneda-Puglianini O, Chavez JC. Bispecific antibodies for non-Hodgkin's lymphomas and multiple myeloma. Drugs Context 2021, 10.

180. Bobin A, Gruchet C, Guidez S, Gardeney H, Nsiala Makunza L, Vonfeld M, Levy A, Cailly L, Sabirou F, Systchenko T et al. Novel non-immunologic agents for relapsed and refractory multiple myeloma: a review article. Cancers (Basel) 2021, 13(20).

181. Nishida H. Rapid progress in immunotherapies for multiple myeloma: an updated comprehensive review. Cancers (Basel) 2021, 13(11).

182. Ye X, Li W, Huang J, Zhang L, Zhang Y: Cytotoxic T cell responses induced by CS1/CRT fusion DNA vaccine in a human plasmacytoma model. Front Oncol. 2020;10:587237.

183. Basher F, Dhar P, Wang X, Wainwright DA, Zhang B, Sosman J, Ji Z, Wu JD. Antibody targeting tumor-derived soluble NKG2D ligand SMIC reprograms NK cell homeostatic survival and function and enhances 
melanoma response to PDL1 blockade therapy. J Hematol Oncol. 2020;13(1):74.

184. Singh N, Lee YG, Shestova O, Ravikumar P, Hayer KE, Hong SJ, Lu XM, Pajarillo R, Agarwal S, Kuramitsu S, Orlando EJ, Mueller KT, Good CR, Berger SL, Shalem O, Weitzman MD, Frey NV, Maude SL, Grupp SA, June $\mathrm{CH}$, Gill S, Ruella M. Impaired death receptor signaling in leukemia causes antigen-independent resistance by inducing CAR T-cell dysfunction. Cancer Discov. 2020;10(4):552-67.

185. Bobin A, Gruchet C, Guidez S, Gardeney H, Nsiala Makunza L, Vonfeld $M$, et al. Novel non-immunologic agents for relapsed and refractory multiple myeloma: a review article. Cancers (Basel) 2021, 13(20).

186. Ye X, Li W, Huang J, Zhang L, Zhang Y. Cytotoxic T cell responses induced by CS1/CRT fusion DNA vaccine in a human plasmacytoma model. Front Oncol 2020, 10:587237.

187. Caraccio C, Krishna S, Phillips DJ, Schurch CM. Bispecific antibodies for multiple myeloma: a review of targets, drugs, clinical trials, and future directions. Front Immunol. 2020;11:501.

188. Lancman G, Sastow DL, Cho HJ, Jagannath S, Madduri D, Parekh SS, et al. Bispecific antibodies in multiple myeloma: present and future. Blood Cancer Discov. 2021;2(5):423-33.

189. Romano A, Storti P, Marchica V, Scandura G, Notarfranchi L, Craviotto $\mathrm{L}$, et al. Mechanisms of action of the new antibodies in use in multiple myeloma. Front Oncol 2021, 11:684561.

190. Bruins WSC, Zweegman S, Mutis T, van de Donk N. Targeted therapy with immunoconjugates for multiple myeloma. Front Immunol. 2020;11:1155.

191. Abdul-Rafae AW, Ehsan H, Christy J, Saleem T, Kandah E, Ali R, Malik M et al. Recent updates on bispecific T-cell engager (BiTE) antibodies in relapsed and refractory multiple myeloma. J Clin Oncol 2021, 39(15) suppl.

192. Wang Y, Li H, Xu W, Pan M, Qiao C, Cai J, et al. BCMA-targeting bispecific antibody that simultaneously stimulates NKG2D-enhanced efficacy against multiple myeloma. J Immunother. 2020:43(6):175-88.

193. Zavidij O, Haradhvala NJ, Mouhieddine TH, Sklavenitis-Pistofidis R, Cai $S$, Reidy M, et al. Single-cell RNA sequencing reveals compromised immune microenvironment in precursor stages of multiple myeloma. Nat Cancer. 2020;1 (5):493-506.

194. Andersen MA, Lauridsen KL, Etzerodt A, Sorensen BS, Abildgaard N, Plesner T, et al. STAT3 is over-activated within CD163pos bone marrow macrophages in both multiple myeloma and the benign pre-condition MGUS. Cancer Immunol Immunother. 2022;71(1):177-87.

195. Bae J, Accardi F, Hideshima T, Tai YT, Prabhala R, Shambley A, et al. Targeting LAG3/GAL-3 to overcome immunosuppression and enhance anti-tumor immune responses in multiple myeloma. Leukemia. 2022;36:138-54

\section{Publisher's Note}

Springer Nature remains neutral with regard to jurisdictional claims in published maps and institutional affiliations.

Ready to submit your research? Choose BMC and benefit from:

- fast, convenient online submission

- thorough peer review by experienced researchers in your field

- rapid publication on acceptance

- support for research data, including large and complex data types

- gold Open Access which fosters wider collaboration and increased citations

- maximum visibility for your research: over $100 \mathrm{M}$ website views per year

At BMC, research is always in progress.

Learn more biomedcentral.com/submissions 